\title{
Actinopterygians of the Stephanian sediments of the Krkonoše Piedmont Basin (Bohemian Massif) and their palaeobiogeographic relationship
}

\author{
STANISLAV ŠTAMBERG
}

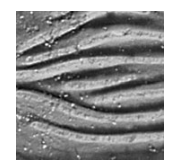

\begin{abstract}
A summary is presented of the skeletal fragments of the Late Carboniferous actinopterygians of the Krkonoše Piedmont Basin (Bohemian Massif) with their description. Progyrolepis speciosus, "Elonichthys" sp., Spinarichthys dispersus and Sphaerolepis kounoviensis are distinguished using all the available material. The relationships between the actinopterygian fauna of the Krkonoše Piedmont Basin and Central and Western Bohemian basins are discussed. Every single taxon from the Carboniferous of the Krkonoše Piedmont Basin is compared with the closest species from basins of Europe and North America. Microsculpture of the teeth and scales of Progyrolepis speciosus from the Bohemian Massif and Progyrolepis heyleri from the French Massif Central are described. The position of the genus Elonichthys and comparison of "Elonichthys" sp. with the type species Elonichthys germari from the Saale Basin in Germany is also discussed. Spinarichthys dispersus inhabited the freshwater environment of the Stephanian B and C of the Bohemian Massif, it is one of the first aeduellids in the Permo-Carboniferous basins of Europe, and it complements a population of the family Aeduellidae. The occurrence of the well-diagnosed species Sphaerolepis kounoviensis is probably restricted to the Upper Carboniferous deposits of the Bohemian Massif as all known finds are from this level. $\bullet$ Key words: Carboniferous, Actinopterygii, Krkonoše Piedmont Basin, Bohemian Massif.
\end{abstract}

ŠTAMBERG, S. 2016. Actinopterygians of the Stephanian sediments of the Krkonoše Piedmont Basin (Bohemian Massif) and their palaeobiogeographic relationship. Bulletin of Geosciences 91(1), 169-186 (18 figures). Czech Geological Survey, Prague. ISSN 1214-1119. Manuscript received August 18, 2015; accepted in revised form December 21, 2015; published online March 15, 2016; issued March 17, 2016.

Stanislav Štamberg, Museum of Eastern Bohemia, Eliščino nábřeži 465, 50001 Hradec Králové, Czech Republic, and Interdisciplinary Research Centre, Faculty of Arts, University Hradec Králové, Rokitanského 62, 50003 Hradec Králové, Czech Republic; s.stamberg@muzeumhk.cz.

The Krkonoše Piedmont Basin is a significant Upper Palaeozoic Basin extending over the northeastern region of the Bohemian Massif. It belongs to a system of intramontaneous basins, which formed in the early post-orogenic phase during the Westphalian and Saxonian times (approximately Moscovian to Sakmarian; Martínek et al. 2006). The basin is filled with continental deposits of total thickness of about $1800 \mathrm{~m}$ of the Upper Carboniferous (Westphalian D, Stephanian), of the Lower Permian to the Triassic.

Actinopterygians were described several times from the Lower Permian sediments of the Krkonoše Piedmont Basin (see Štamberg \& Zajíc 2008). The actinopterygians from the Stephanian sediments of the Krkonoše Piedmont Basin are on the other hand very rare and fragmentary. Primary data about isolated actinopterygian scales from Stephanian C were previously published by Frič (1912a, b). Lists of the Stephanian faunas were recently part of the publications summarizing the geology of the Krkonoše
Piedmont Basin (Prouza \& Tásler 2001, Zajíc \& Vašíček 2010) and were also a component part of biostratigraphical studies (Zajíc 2000, 2004, 2007). Inasmuch as the Actinopterygian remains are very fragmentary, they have not been described in great detail, the exception being the scales of Sphaerolepis kounoviensis (Frič, 1876) from the locality Krsmol (Štamberg 2001). The following descriptions and illustrations of actinopterygian scales and bones should contribute to a more exact determination of the taxa from the Stephanian of the Krkonoše Piedmont Basin and make possible the comparison with actinopterygian fauna from other continental Permo-Carboniferous basins.

\section{Geological record}

Remains of actinopterygians are very fragmentary in the Stephanian of the Krkonoše Piedmont Basin. They are represented by scales, isolated bones and teeth. Even 
though they are very rare in the Syřenov Formation (Stephanian B), they are more numerous in the Semily Formation (Stephanian C), where they are accumulated in two significant fossiliferous horizons, namely ŠtěpaniceČikvásky Horizon and Ploužnice Horizon (Fig. 1). These horizons, according to current understanding, represent two different facies of the same age. They are several tens of metres thick and contain different types of sediment (Tásler et al. 1980, Prouza \& Tásler 2001). The described horizons correspond more to members rather than horizons (after Zajíc 2007). The terms Štěpanice-Čikvásky Lake Deposits and Ploužnice Lake Deposits were introduced by Zajíc (2007) and are used in this paper instead of horizons until an exact definition of the members corresponding to the above mentioned horizons has been decided. Štěpanice-Čikvásky Lake Deposits occur in the northern region of the basin; the fossils are accumulated mainly in grey and grey-black, fine laminated mudstones with coal laminae. Ploužnice Lake Deposits occur in the southern part of the basin and are distinguished by varicoloured laminated mudstones with layers of limestones and tuffaceous intercalations (Prouza \& Tásler 2001). Actinopterygian remains are restricted to the varicoloured mudstones and a thin layer of bone bed. Zajíc (2007) described in more detail the palaeogeography and lithostratigraphy of Ploužnice Lake. A list of Stephanian age localities in the Krkonoše Piedmont Basin was published by Zajíc (2007) and Štamberg \& Zajíc (2008).

\section{Material and methods}

Material used in this study originates from old collections and from new findings. The old material is from collections of the turn of the nineteenth to the twentieth century. Numerous collections of faunal fragments from localities in the vicinity of Ploužnice, Kyje and Žd'ár u Kumburku are deposited in museums thanks to the collector Mr Jan Benda (1855-1919), head teacher in the town Lomnice nad Popelkou. The biggest collection is in the National Museum, Prague, smaller collections, originally from Jan Benda, are deposited in the Museum of Eastern Bohemia in Hradec Králové, the Museum of Czech Paradise in Turnov, the Municipal Museum in Lomnice nad Popelkou and the Municipal Museum in Nová Paka. An excellent collection of material from Ploužnice Lake, collected also by Mr Jan Benda, is housed in the Geologisches Bundesanstalt in Vienna. Material from boreholes and Štěpanice-Čikvásky Lake Deposits were collected at the end of the twentieth century, and are housed with the Czech Geological Survey in Prague. An important collection of new material from the dump of the Otto adit of the Štěpanice-Čikvásky Lake Deposits is in the Museum of Eastern Bohemia in Hradec Králové.

Fragments of actinopterygians, namely isolated scales, teeth and bones, in total number several hundred speci- mens are preserved in the red-brownish calcareous siltstones and claystones of the Ploužnice Lake Deposits and in the black-greyish claystones of the ŠtěpaniceČikvásky Lake Deposits. Most of the fragments are preserved as imprints of the outside of the scales.

A collection of specimens of Progyrolepis heyleri Poplin, 1999 from the locality Buxières-les-Mines (Aumance Basin, French Massif Central), which is under the care of the Association Rhinopolis in Buxières-les-Mines, was used as comparative material. Some results from personal observation of the holotype of the type species of Elonichthys germari Giebel, 1848 deposited in the Institute of Geoscience of Martin-Luther University in Halle, served as a comparison for the scales of "Elonichthys" sp. Some specimens were prepared using a Krantz pneumatic needle. A SEM Hitachi S-3700N was used for study and documentation of the tooth microsculpture of suitable scales. Source for determination and comparison of isolated actinopterygian fragments were the comprehensive papers on actinopterygians of the Central and West Bohemian Upper Palaeozoic basins (Fritsch 1895; Štamberg 1986, 1991) and other review publications (Štamberg 1985, 1989, 2013).

Institutional abbreviations. - BX - Association Rhinopolis of Buxières-les-Mines, France; D - Association Rhinopolis of Buxières-les-Mines, France; GBW - Geologisches Bundesanstalt in Vienna, Austria; LS - Czech Geological Survey, Prague, Czech Republic; M - National Museum, Prague, Czech Republic; MHK - Museum of Eastern Bohemia in Hradec Králové, Czech Republic.

\section{Systematic palaeontology}

Subclass Actinopterygii Cope, 1877

Family Pygopteridae Aldinger, 1937

\section{Genus Progyrolepis Fritsch, 1895}

Type species. - Progyroleopis speciosus (Frič, 1875).

\section{Progyrolepis speciosus (Frič, 1875)}

Figures 2-4

Material. - Isolated scales and teeth Nos. GBW 2006/54/6, GBW 2006/54/17, GBW 2006/54/29, LS84-Št3, LS84-Št4, LS84-ك̌t5, M 4888.

Occurrence. - Black shale Horizon of the Syřenov Formation (Stephanian B) - locality: Libštát "Borehole Lt-1", and varicoloured mudstone from the Ploužnice Lake Deposits of the Semily Formation (Stephanian C) - locality: Žd'ár u Kumburku. 

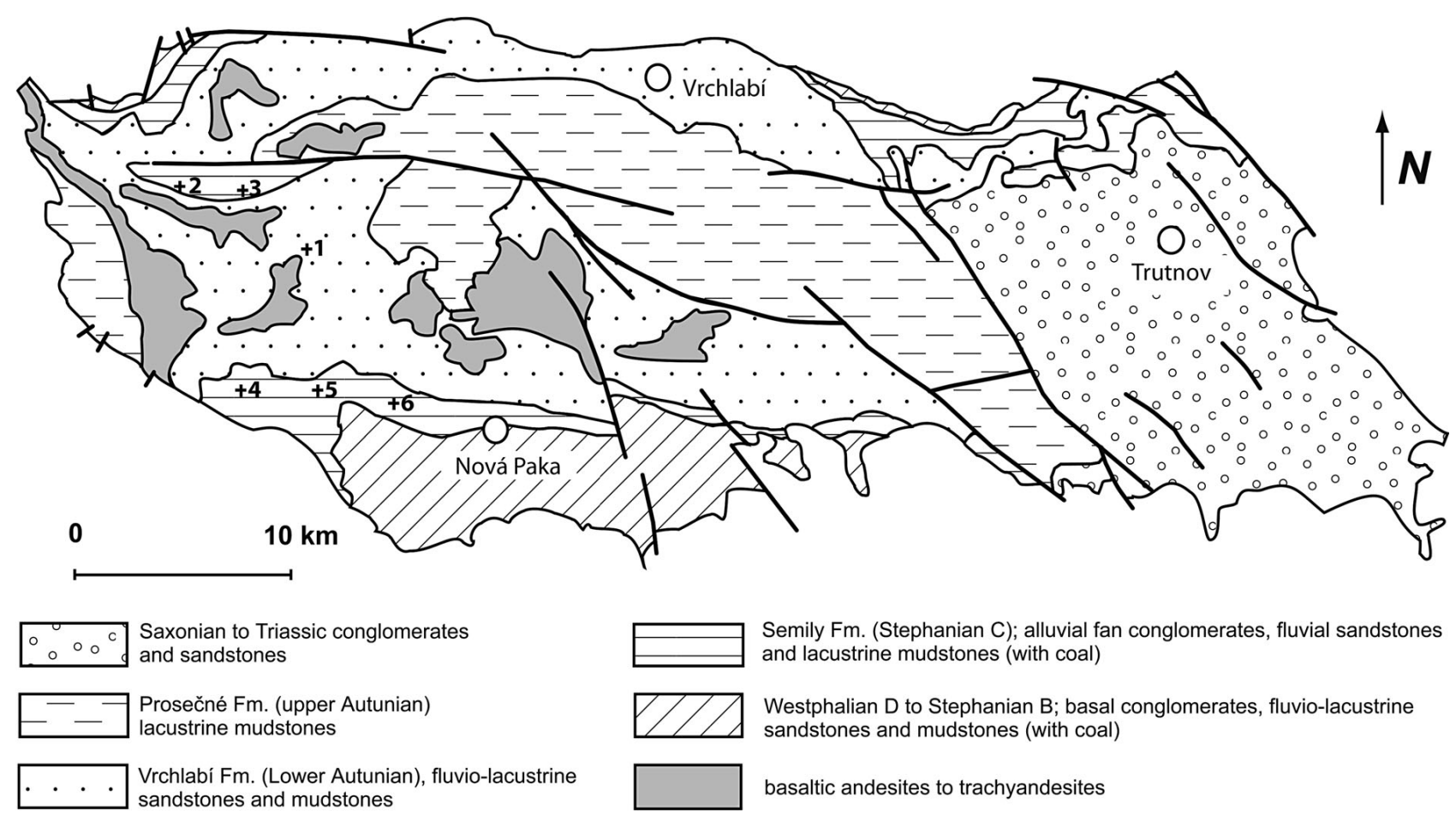

Semily Fm. (Stephanian C); alluvial fan conglomerates, fluvial sandstones and lacustrine mudstones (with coal)

Westphalian D to Stephanian B; basal conglomerates, fluvio-lacustrine sandstones and mudstones (with coal)

Figure 1. A simplified geological map of the Krkonoše Piedmont Basin (based on Blecha et al. 1999) showing of some important localities with the Carboniferous faunas. 1 - Libštát "Borehole Lt-1"; 2 - Nedvězí "Dump of the Otto adit"; 3 - Koštálov "Dump of the Naděje adit"; 4 - Ploužnice; 5 - Žd'ár u Kumburku; 6 - Krsmol.
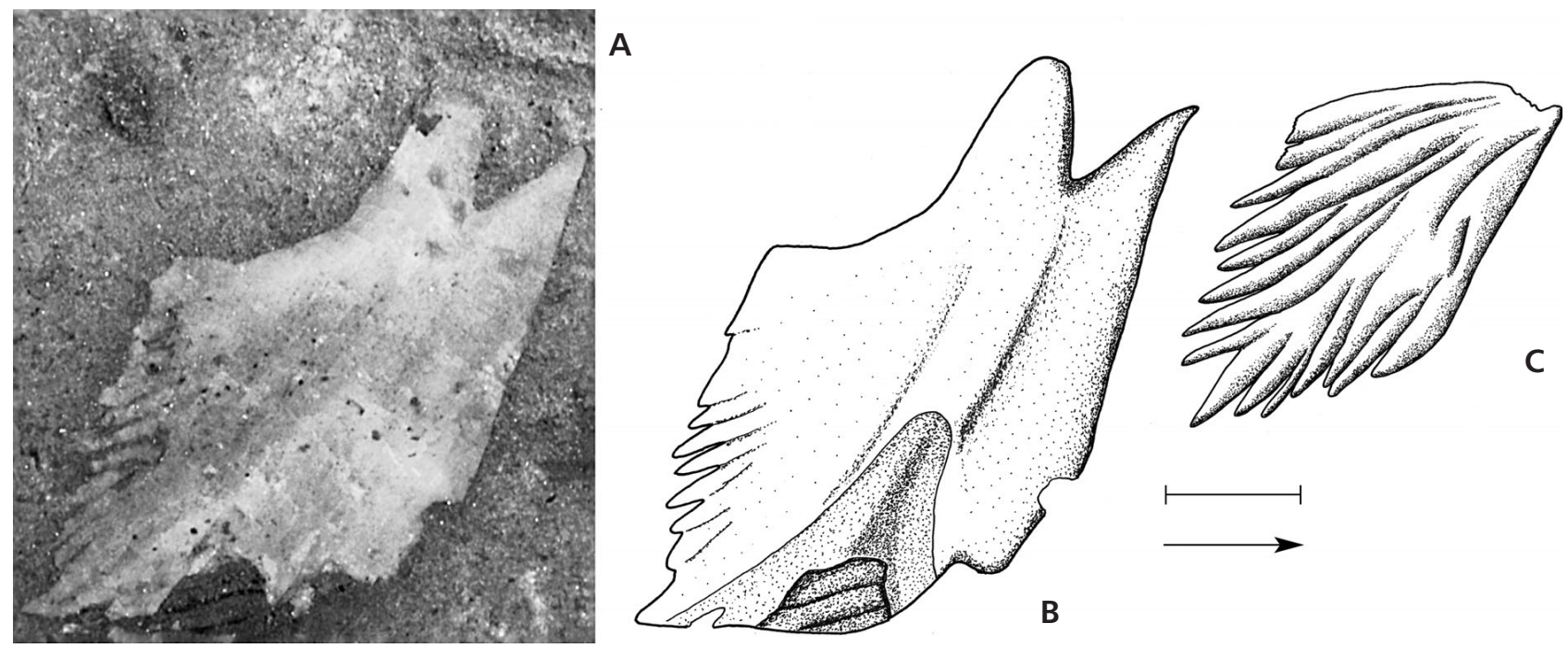

Figure 2. Progyrolepis speciosus (Frič, 1875). Locality Žd’ár u Kumburku. Scale bar 1 mm, arrow indicates directio cranialis. • A, B - photograph and drawing drawing of the flank scale GBW 2006/54/29 in medial view. • C - drawing of the guanine surface of the ganoid scale GBW $2006 / 54 / 6$ from the base of the anal fin in lateral view.

Description. - Thick isolated scales measuring 3.5-4.5 mm long. The scales from the anterior region of the body have a length equivalent to their height. A conspicuous strong peg has a wide base and is situated on the dorsal border of the scale closer to its anterior margin than to the posterior one (Fig. 2). The scales have prominent ganoin ridges on their outer surface. The ridges pass diagonally from the anterodorsal corner of the scale to the posterior border where they terminate posteriorly with serrations (Fig. 2A, B). The ridges also terminate with serrations on the ventral border on some scales around the anal fin base (Fig. 2C). There are 10 to 12 ridges on the outer surface of the scales depending on 


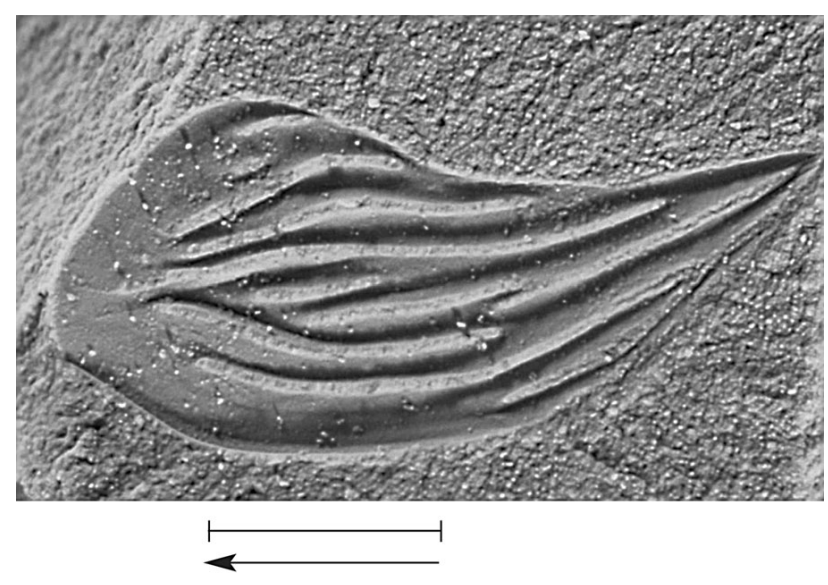

Figure 3. Progyrolepis speciosus (Frič, 1875). Imprint of the scale LS84-Št3 from the caudal peduncle in lateral view. Borehole Lt-1 (Libštát), depth $805.5 \mathrm{~m}$. Scale bar $1 \mathrm{~mm}$, arrow indicates directio cranialis.

the body position. The scales from the ventral region of the trunk are oblong in shape; the scales are 2.5 times longer than deep. Conspicuous ridges on their outer surface traverse from the anterior margin of the scale and terminate with five serrations on the posterior margin (LS84-Št4). The scale from the caudal peduncle (Fig. 3) is of rhombic shape, narrow posteriorly. Eight ridges form the sculpture on its outer surface; they do not extend across the entire lateral surface.
The isolated conical tooth LS84-Št5 is $3.8 \mathrm{~mm}$ long, it has a wide base and a distinctively different acrodin apex (Fig. 4B). The acrodin apex is $0.5 \mathrm{~mm}$ long. The corpus of the tooth is sculptured, with the exception of the acrodin apex, with shallow ridges uniformly directed from the acrodin apex to the base of the tooth. There are 11 or 12 of these longitudinal ridges on the visible half of the tooth, it can be supposed there are 22 to 24 longitudinal ridges on the whole periphery. A different fine microsculpture is observable on the whole surface of the tooth, with the exception of the acrodin apex. This fine microsculpture is formed by fine protuberances convolutedly distributed on the surface of the tooth. The elliptical protuberances are proximo-distally elongated, and confluent in several places (Fig. 4C). The distribution of the protuberances corresponds to the description of the tooth ornament in the type material of Progyrolepis speciosus by Fritsch (1895, pl. 32, figs 4-6).

Remarks. - The scales of the type material of Progyrolepis speciosus from the Kounov Member (Stephanian B) of the Central and West Bohemian Late Paleozoic basins figured by Fritsch $(1895$, pl. 131, figs 4-9, 11) and revised by the present author (Štamberg 1989, fig. 4, 1991, fig. 23) have no tooth-like projections on their posterior margin; the descriptions were confirmed by personal observation. It became apparent that poor preservation of the scales affected these inaccurate deductions. Other material (M 4754,
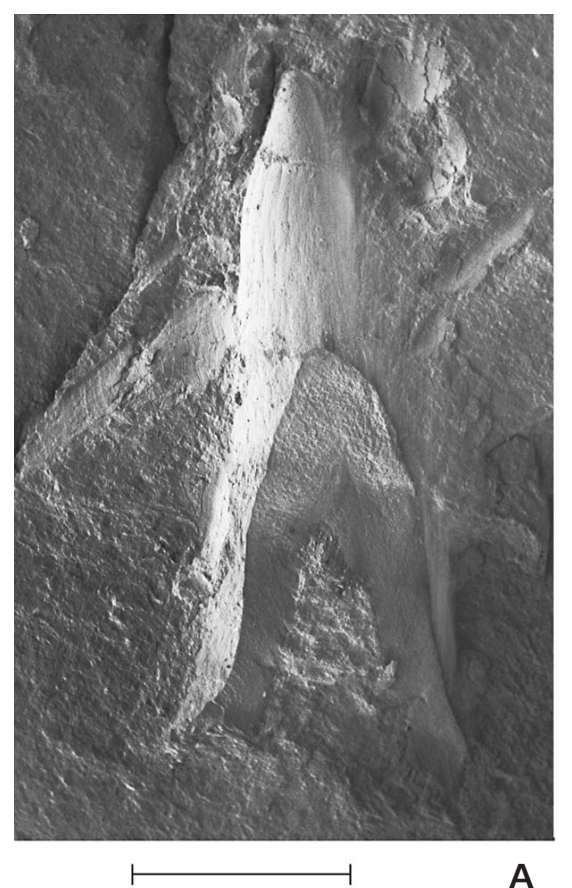

A

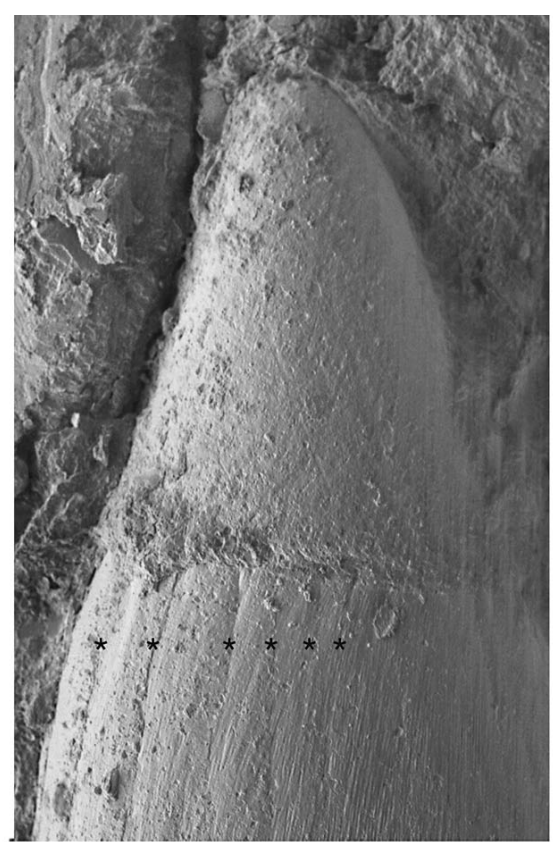

B

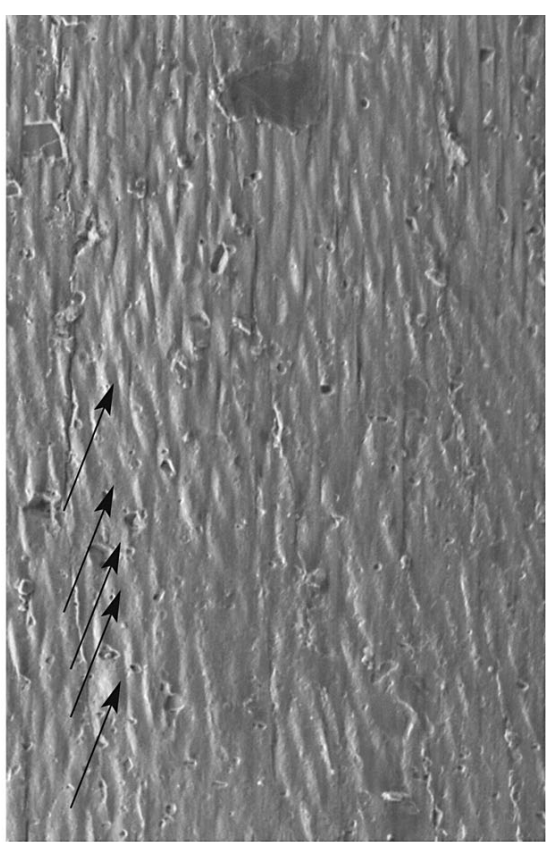

C

Figure 4. Progyrolepis speciosus (Frič, 1875). Isolated tooth LS84-Št5. Borehole Lt-1 (Libštát), depth 805.25 m. • A - whole tooth. Scale bar 1 mm. - B - the distal part of the tooth with fine ridges (asterisks) and acrodin apex. Scale bar $500 \mu \mathrm{m}$. $\bullet \mathrm{C}$ - fine protuberances on the periphery of the tooth are arranged in rows convolutedly winding around the tooth. Arrows indicate arrangement of the rows. Scale bar $100 \mu \mathrm{m}$. 


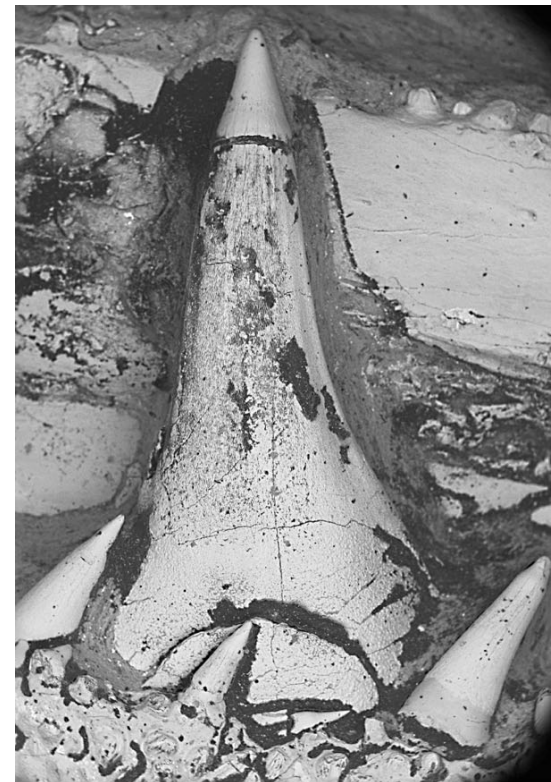

$\longmapsto$

A

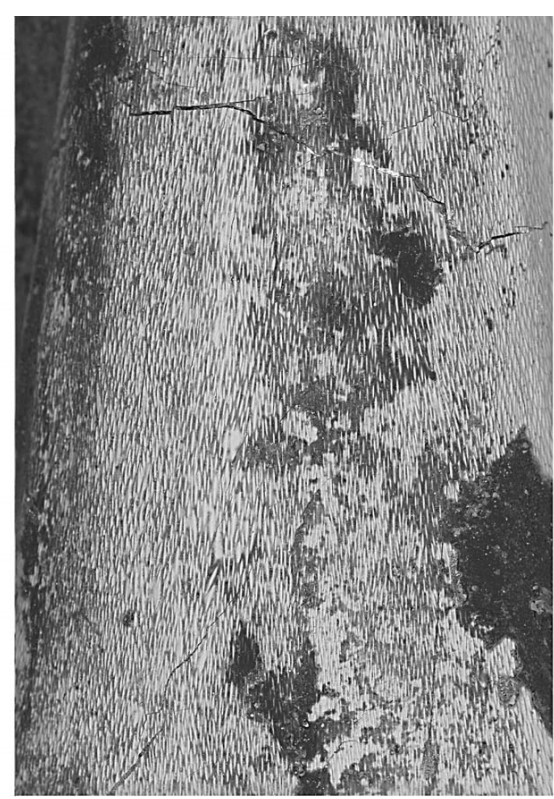

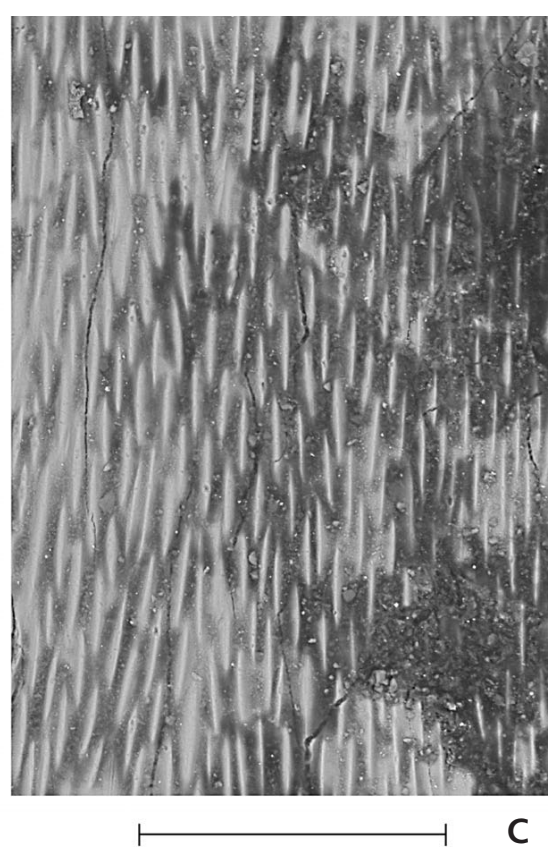

Figure 5. Progyrolepis heyleri Poplin, 1999. Specimen BXM 094, Buxières-les-Mines. • A - large tooth of the internal row and much smaller three teeth of the outer row of the lower jaw. Scale bar $1 \mathrm{~mm}$. $\bullet \mathrm{B}, \mathrm{C}-$ microsculpture on the large tooth. Scale bars $100 \mu \mathrm{m}$.

M 4755) from the Kounov Member demonstrates that there were also well-preserved scales with outstanding serration on their posterior margin besides the bones of Progyrolepis speciosus. The serration is one of the features of the scales of Progyrolepis speciosus if the scales are well preserved. Correction of the species diagnosis of Progyrolepis speciosus published by Stamberg (1991) is necessary with respect to this feature, and one character in the diagnosis "Caudal margin of scales not serrated" must be replaced by "Caudal margin of scales is serrated".

Progyrolepis speciosus was also reported by SolerGijón (1997) from the Stephanian C of the Puertollano Basin in Spain. The genus Progyrolepis is also represented in the Permian sediments of the Aumance Basin (French Massif Central) in the locality Buxières-les-Mines. Poplin (1999) described a new species, Progyrolepis heyleri Poplin, 1999, from this locality based on the upper and lower jaws. Studies of the microsculpture of the large teeth of the internal row and much smaller teeth of the outer row demonstrate a match with the microsculpture of $P$. speciosus. The acrodin apex of $P$. heyleri teeth is smooth, but the remaining part of the tooth corpus is sculptured with longitudinal ridges distributed around the periphery of the teeth (Fig. 5A). In addition a different fine microsculpture is observable on the whole surface of the tooth, with the exception of the acrodin apex. The fine microsculpture is formed by fine protuberances distributed on the surface of the tooth. The elliptical protuberances are proximo-distally elongated, spaced from each other and only sometimes touching each other (Fig. 5B, C). The same microsculpture

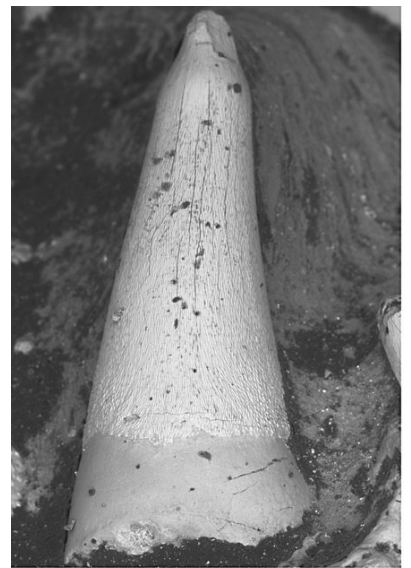

A

Figure 6. Progyrolepis heyleri Poplin, 1999. Specimen BXM 094, Buxières-les-Mines. One of the small teeth of the outer row figured on the Fig. 5A. • A - detail of the tooth. Scale bar $100 \mu \mathrm{m}$. $\bullet$ B - microsculpture on the tooth. Scale bar $100 \mu \mathrm{m}$.

can also be observed on the small teeth of the outer row, with less space between the protuberances (Fig. 6). The microsculpture is not exclusive on teeth of Progyrolepis speciosus as described by Poplin (1999), but it is also common in $P$. heyleri. The scales of $P$. heyleri are briefly described in comparison to the scales of $P$. speciosus from the Krkonoše Piedmont Basin. These scales are conspicuously serrated on their posterior margin but not only in the anterior region of the body but also in the posterior region of the body and on the caudal peduncle. The entire posterior edge 

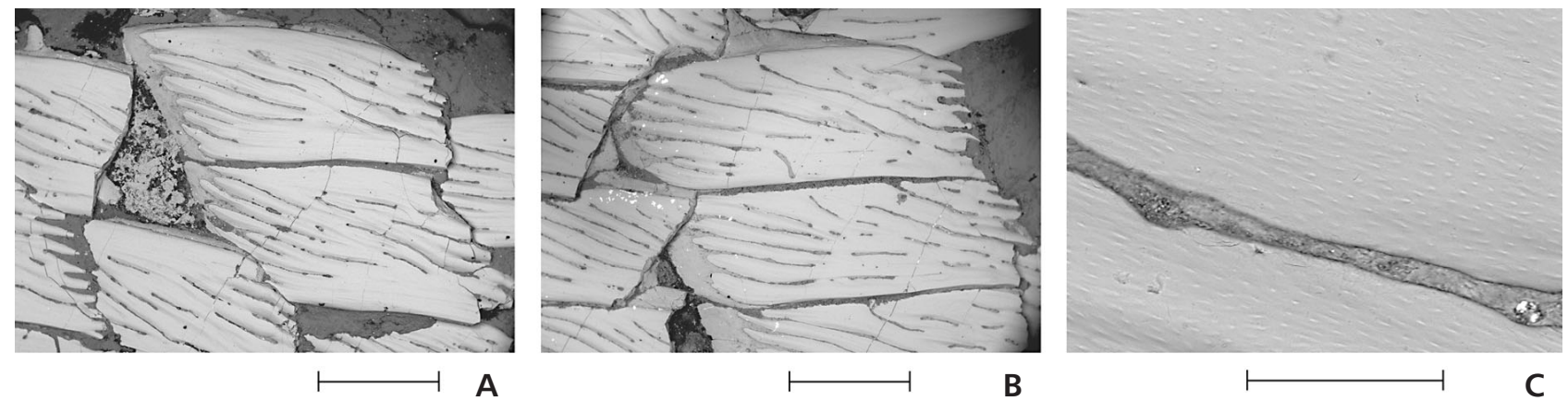

Figure 7. Progyrolepis heyleri Poplin, 1999. Specimen D 17-0896, Buxières-les-Mines. $\bullet$ A - the scales from the anterior region of the lateral side of the body. Scale bar $1 \mathrm{~mm}$. $\bullet \mathrm{B}$ - the scales from the ventral side of the body. Scale bar $1 \mathrm{~mm}$. $\bullet \mathrm{C}-$ microsculpture on the scale from the ventral side of the body. Scale bar $100 \mu \mathrm{m}$.

of the scales is serrated (Fig. 7B). Serration of the posterior margin of the scales in $P$. heyleri is much more conspicuous than in P. speciosus. Sculptured scales show conspicuous ridges diagonally crossing the outer surface of the scales (Fig. 7A, B). The microsculpture on the scales is formed by microtubercles arranged in the same direction as the ridges. The microtubercles have an elliptical base, antero-posteriorly elongated (Fig. 7C), and they are more elongated and less numerous than in "Elonichthys" sp. (Fig. 9B). Microtubercles are typical for ganoin (Schultze 2015), and they are present also in Palaeozoic actinopterygians Strepheoschema fouldenensis White, 1927 and Palaeoniscum freieslebeni Blainville, 1818 (Richter 1995), besides the species described in this paper. Much osteological material of $P$. heyleri was collected from the locality of Buxières-les-Mines, but has not been elaborated to date.

Family Elonichthyidae Aldinger, 1937

\section{Genus Elonichthys Giebel, 1848}

Type species. - Elonichthys germari Giebel, 1848.

\section{"Elonichthys" sp.}

Figures 8-10

Material. - Isolated lower jaw M 4889, teeth and scales LS85-Št2, M 4887-M 4901, M 4903-M 4906, MHK 81330, MHK 81342, MHK 81343, MHK 81349.

Occurrence. - The isolated scale LS85-Št2 originates from the Black Shale Horizon of the Syřenov Formation (Stephanian B) - locality: Libštát "Borehole Lt-1", other isolated scales, teeth and one fragment of lower jaw are from the Ploužnice Lake Deposits (Stephanian C) - localities: Ploužnice, Žd'ár u Kumburku, and from the Štěpanice-Čikvásky Lake Deposits (Stephanian C) - locality: Nedvězí "Dump of the Otto adit".
Description. - A fragment of a lower jaw on M 4889 shows a sculpture of ridges passing slightly obliquely anteroposteriorly. The sculpture corresponds to that figured by Štamberg (1991, fig. 5) on "Elonichthys" krejcii (Fritsch, 1895) and on Elonichthys sp. from the Late Carboniferous of the Boskovice Graben (Štamberg 2007). Ridge scales are well preserved on samples M 4887, M 4898, MHK 81330 and MHK 81349. These scales, which correspond in their shape and sculpture to those described by Štamberg (1991), were located in front of the dorsal fin or on the dorsal margin in front of the caudal fin (Fig. 8). They are from 4 to $5 \mathrm{~mm}$ wide and from 6 to $8 \mathrm{~mm}$ long. They are conspicuously deeply cleft anteriorly. The uncovered posterior region of the scale is sculptured with ridges arranged antero-posteriorly. The isolated scales from the lateral side of the body are relatively very small, $1.5-2 \mathrm{~mm}$ long and $1.2-1.5 \mathrm{~mm}$ deep. The scales possess diagonal ridges or furrows. The longest ridge or furrow passes diagonally from the anterodorsal corner to the posteroventral corner of the scale, and it terminates in a dental form process on the posterior margin of the scale (Fig. 9A, C). This long ridge or furrow divides the lateral surface of the scale into the anteroventral and posterodorsal halves. The arrangement of ridges on the two halves is different. From six to seven ridges are recognizable on the anteroventral region of the scale. They run parallel to the ventral margin. The posterodorsal halve of the scale has one or two ridges which start at the anterodorsal corner of the scale. They branch posteriorly, and terminate in eight or more dents (Fig. 9A). Microtubercles are as well preserved on the ridge scales (Fig. 8C) as on the scales of the lateral side of the body (Fig. 9B, D). They are slightly antero-posteriorly elongated, but not as conspicuously as in Palaeoniscum freieslebeni Blainville, 1818 or Strepheoschema fouldenensis figured by Richter (1995) or Progyrolepis heyleri Poplin, 1999 (personal observation). They are clearly different from the microtubercles of Spinarichthys dispersus, in which the base has a circular outline (Fig. 12B).

Numerous finds of teeth are assigned to "Elonichthys" 


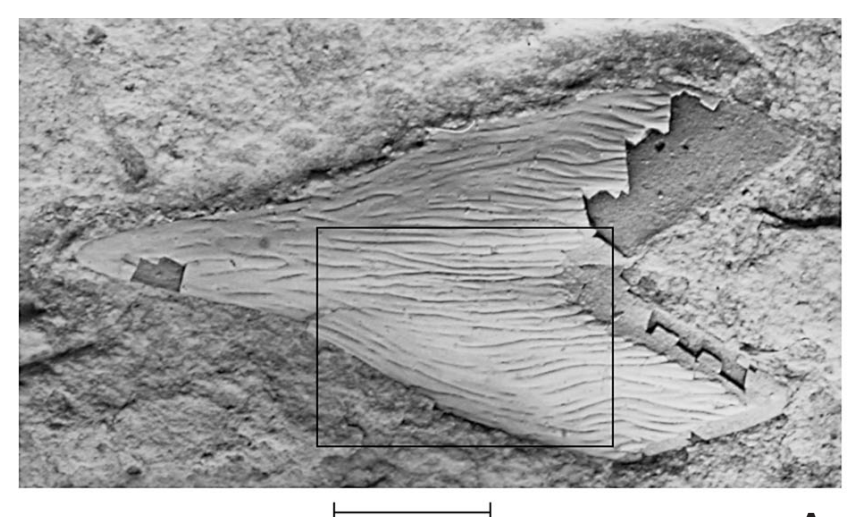

A

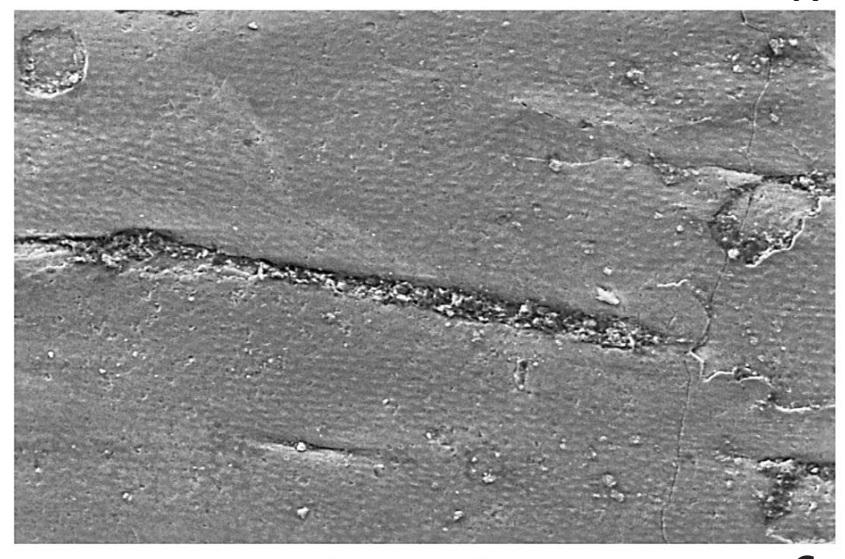

C

sp. on the basis of comparison with the type material (Štamberg 1991) of "Elonichthys" krejcii (Fritsch, 1895). The slender, sharp pointed teeth are 1.5-1.7 $\mathrm{mm}$ in length and the width of their base is $0.6 \mathrm{~mm}$. The distinct acrodin apex has a length of $0.3 \mathrm{~mm}$ (Fig. 10A). The teeth are without distinct visible sculpture; there are no longitudinal ridges on the periphery, which are known in Progyrolepis. On the other hand, microtubercles are well developed. They cover the whole surface of the tooth, with the exception of the acrodin apex. Microtubercles are proximo-distally elongated, they are narrower, more elongated and blend together (Fig. 10B, C), and the oblique rows are not as distinct as in Progyrolepis (Fig. 4C). These distinctions can however be caused by the varying degrees of abrasion on the teeth during the course of their transportation, and thus further study of well preserve material is necessary.

Remarks. - Isolated scales and teeth from the Krkonoše Piedmont Basin are assigned to the genus "Elonichthys" Giebel, 1848 on the basis of comparison with more complete material of "Elonichthys" krejcii (Fritsch, 1895) from the Carboniferous of the Central and West Bohemian late Palaeozoic basins (Fritsch 1895; Štamberg 1991, 2010, 2013). The use of the genus name Elonichthys for actinopterygians from the Bohemian Massif is questionable and therefore in quotation marks (Štamberg 2010, 2013) due to

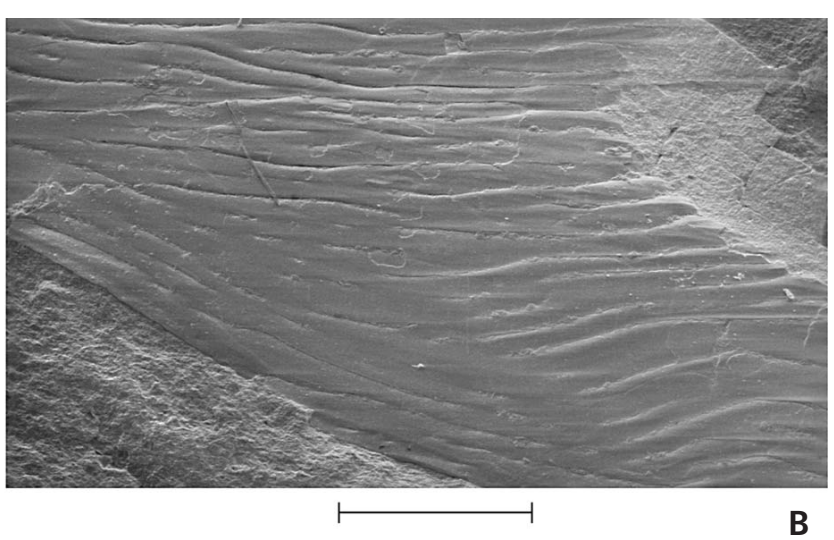

Figure 8. "Elonichthys" sp. Ridge scale M 4898 from the locality Ploužnice. - A - whole scale. Small frame marks the shot on Fig. 8B. Whitened, scale bar $1 \mathrm{~mm}$. $\bullet$ B - detail of the sculpture. Scale bar $500 \mu \mathrm{m}$. - $\mathrm{C}$ - detail of the microsculpture on the outer surface of the ridge scale. Scale bar $100 \mu \mathrm{m}$.

the fact that an up to date revision of the Elonichthys type material is still not available. Many species from freshwater and mainly marine Carboniferous and Permian sediments in Germany, England and North America were assigned to the genus Elonichthys. A basic revision of Elonichthys germari Giebel, 1848 type species is however lacking. Gardiner (1963) presented a diagnosis of Elonichthys, but without study of the type material, and in his remarks refers to the necessity for a redefinition of the genus Elonichthys. Schindler (Poschmann \& Schindler 2004) formulated the last definition of the family Elonichthyidae Aldinger, 1937, and he considered the genus Elonichthys to be exclusively freshwater (Poschmann \& Schindler 2004, Schindler 2007). The present author made a brief examination of the type material of the Elonichthys germari type species, and basic comparison of the scales of E. germari and "Elonichthys" sp. from the Krkonoše Piedmont Basin. The type material of Elonichthys germari originates from the continental Saale Basin (Germany), more specifically from the Siebigerode Formation, Wettin Subformation (Stephanian C) (Schneider et al. 2005, Schindler 2009). The scales are preserved on the disarticulated specimen figured by Giebel (1849, pl. 30, fig. 1) deposited in the Martin-Luther University in Halle, Institute of Geosciences. The scales on the whole trunk are ornamented with conspicuous ridges, which pass diagonally downward, and backwards across 

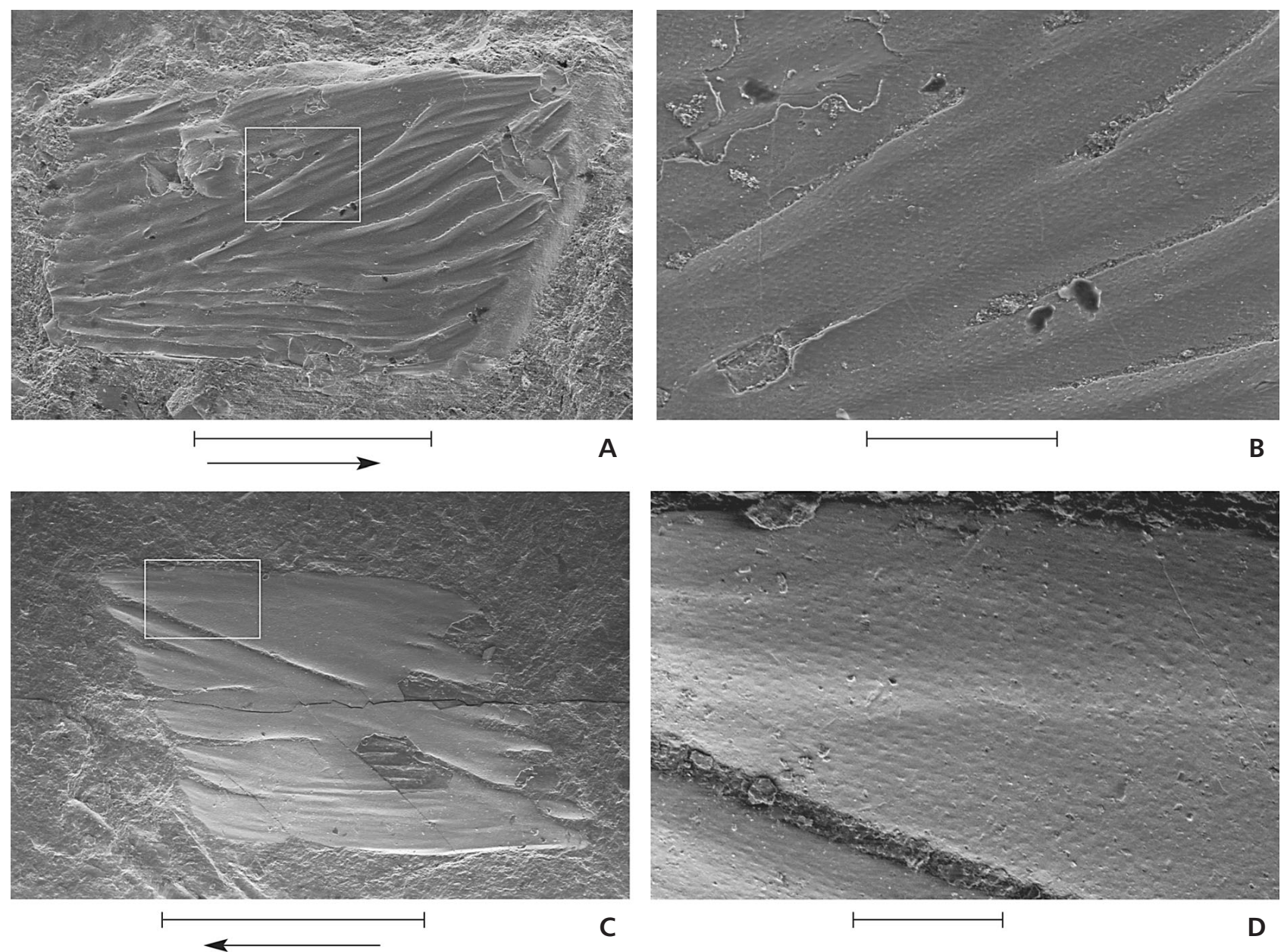

Figure 9. "Elonichthys" sp. • A - isolated scale M 4899 from the locality Ploužnice. Small frame marks the shot on Fig. 9B. Scale bar 1 mm. Arrow indicates directio cranialis. $\bullet$ B - detail of the sculpture and microsculpture. Scale bar $200 \mu \mathrm{m}$. $\bullet$ - isolated scale LS85-Št2, borehole Lt-1 (Libštát), depth $805.5 \mathrm{~m}$. Small frame marks the shot on Fig. 9D. Scale bar $1 \mathrm{~mm}$. Arrow indicates directio cranialis. $\bullet D-$ detail of the microsculpture. Scale bar $100 \mu \mathrm{m}$.

the scale (Fig. 11A), and posteriorly terminate in numerous serrations. The outer surface of the scales on the anterior region of the body is divided into two sections by the longest ridge, which passes diagonally from the dorso-anterior corner of the scale to the ventro-posterior corner. This long ridge divides the lateral surface of the scale into the anteroventral and posterodorsal halves. The arrangement of ridges on the two halves is different (Fig. 11A). Ridges on the anteroventral half start from the anterior border of the scale, they do not anastomosis, and they always end at the longest diagonal ridge, none of these ridges reach the posterior border of the scale. They run parallel to the ventral border of the scale like in Elonichthys sp. (Fig. 9A). The ridges of the posterodorsal half on the contrary run oblique from anterodorsal to the posterior margin start at the anterodorsal corner above the longest diagonal ridge, and they gradually branch out in a posterior direction and terminate in denticulations. The scales from the posterior and ventral regions of the body show a similar division into two parts but with the anteroventral part conspicuously larger than the posterodorsal part (Fig. 11B, C). Peg and socket articulation is well developed. The relative overlay of the scales in the anteroposterior direction is very short, about $1 / 9$ of the scale length (Fig. 11B).

Family Aeduellidae Romer, 1945

\section{Genus Spinarichthys Štamberg, 1986}

Type species. - Spinarichthys dispersus (Fritsch, 1894).

\section{Spinarichthys dispersus (Fritsch, 1894)}

Figures 12, 13

Material. - Numerous isolated scales, the best ones are on M 4895, M4896, LS 84-ك̌t6, GBW 2006/54/38, GBW 2006/54/39, GBW 2006/57/20, MHK 80184, MHK 81336, 


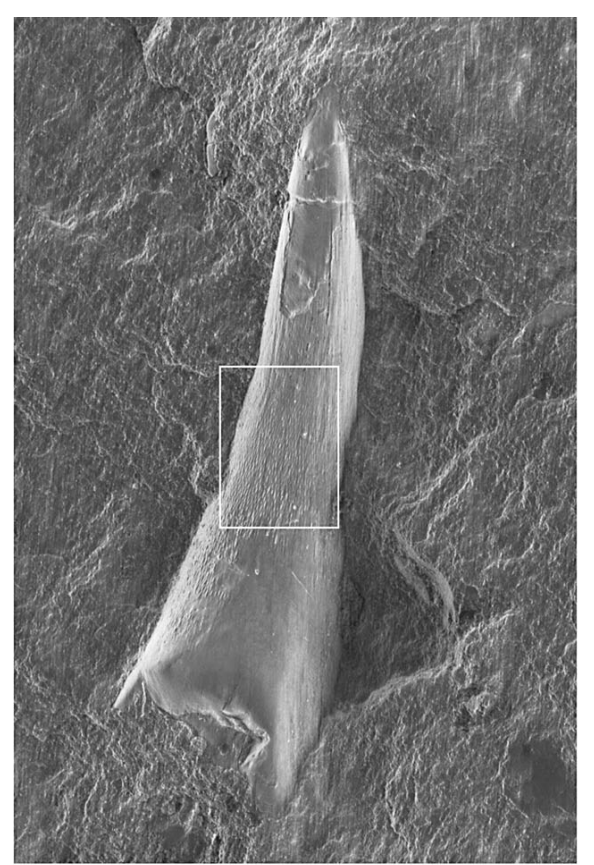

A

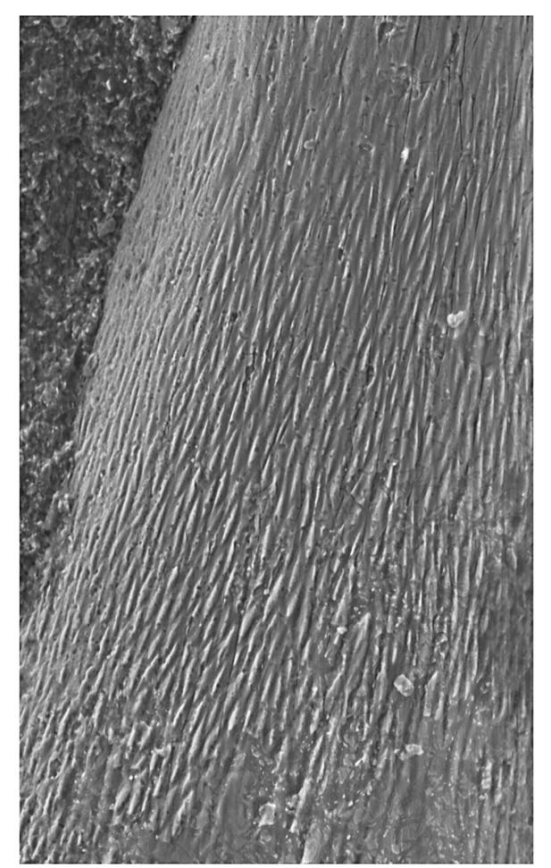

$\longmapsto \quad B$

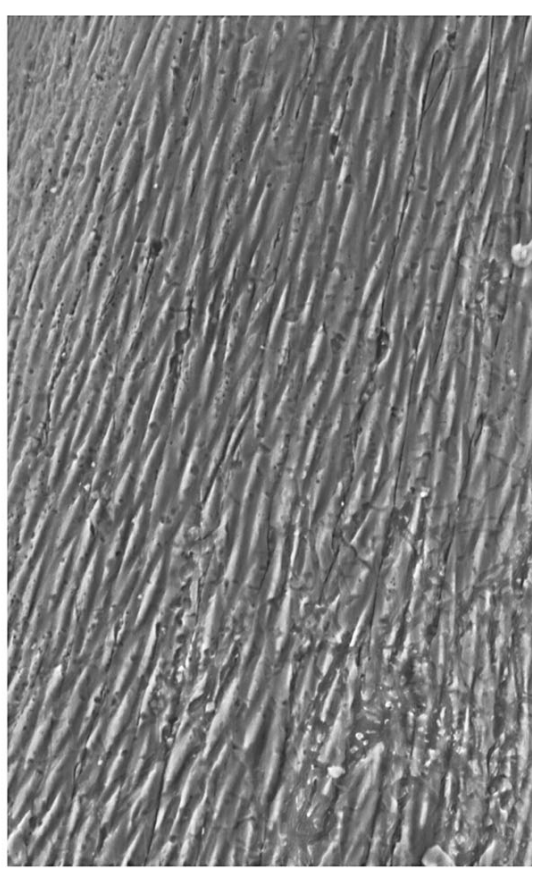

C

Figure 10. "Elonichthys" sp. Isolated tooth M 4900 from the locality Ploužnice. • A - whole tooth. Small frame marks the shots on Fig. 10B, C. Scale bar $500 \mu \mathrm{m} . \bullet \mathrm{B}, \mathrm{C}-$ microtubercles on the tooth. Scale bars $100 \mu \mathrm{m}$.

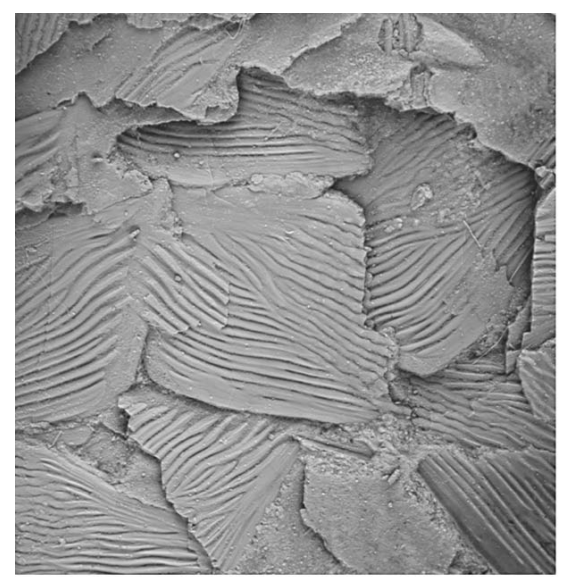

A

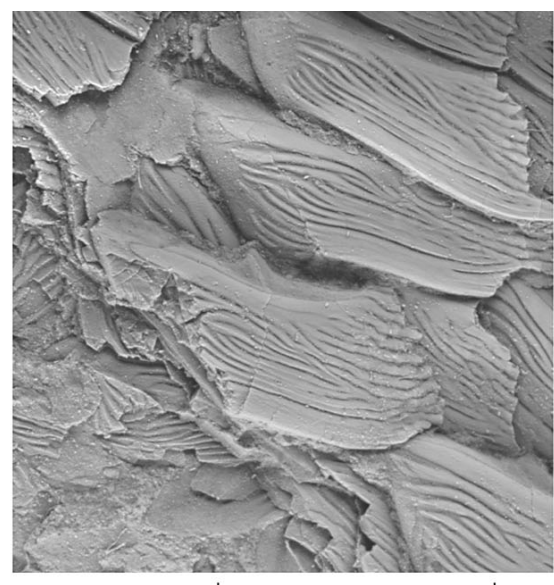

B

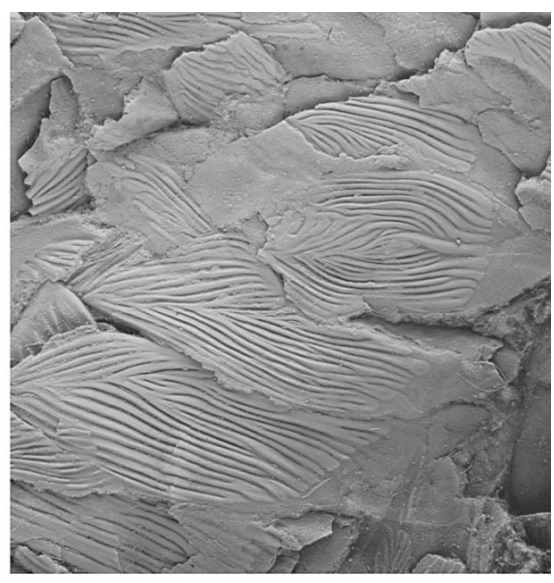

C

Figure 11. Elonichthys germari Giebel, 1848. The scales from the different regions of the body. Whitened, scale bar $5 \mathrm{~mm} \cdot \bullet \mathrm{A}-$ the scales from the anterior region of the trunk. $\bullet \mathrm{B}$ - the scales from the ventral side of the trunk. $\bullet \mathrm{C}$ - the scales from the posterior region of the trunk.

MHK 81344, MHK 81348, MHK 81354 and an isolated operculum MHK 81338.

Occurrence. - The scales come from the Ploužnice Lake Deposits (Stephanian C) - localities: Ploužnice, Kyje, Žd’ár u Kumburku; Štěpanice-Čikvásky Lake Deposits (Stephanian C) - localities: Nedvězí "Dump of the Otto adit", Koštálov "Dump of the Naděje adit". One sample (LS84-Št6) is from the Black Shale Horizon of the Syřenov Formation (Stephanian B) - locality: Libštát "Borehole Lt-1".
Description. - The scales are oblong in shape, anteroposteriorly elongated, and $2-3.5 \mathrm{~mm}$ long. The outer surface of the scales is without sculpture. The posterior margin of the scales is pectinated (Figs 12A, 13). The number of these pectinations on the posterior margin of the scales varies in accordance with the position of the scale on the body. The scales of the lateral side of the body along the lateral sensory line between the supracleithrum and the origin of the dorsal fin have 10-12 serrations (GBW 2006/54/38, GBW 2006/57/20), the scales situated more 


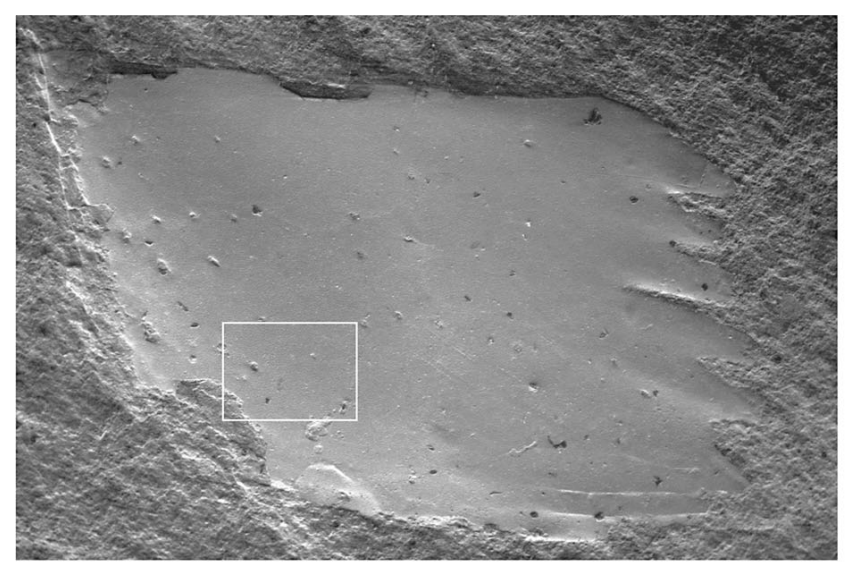

$\longleftarrow$

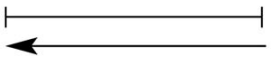

A

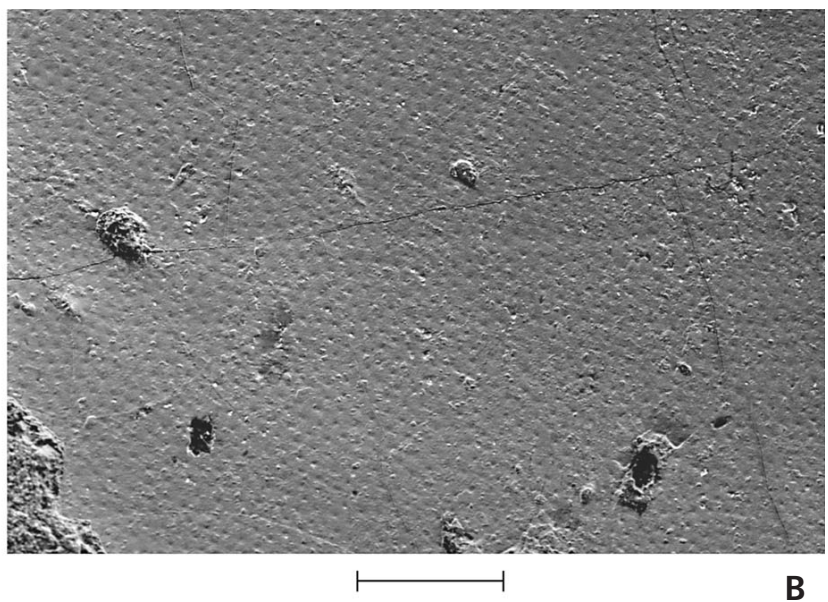

Figure 12. Spinarichthys dispersus (Fritsch, 1894). Isolated scale M 4896 from the locality Ždár u Kumburku. Arrow indicates directio cranialis. - A - isolated scale. Small frame marks the photo on Fig. 12B. Scale bar $1 \mathrm{~mm}$. B - microtubercles on the outer surface of the scale. Scale bar $100 \mu \mathrm{m}$.

posteriorly have about eight serrations (M 4895), and even fewer if they come from the posterior or ventral parts of the trunk. The tall slender process of the peg and socket articulation on the dorsal margin of the scales is an outstanding feature of Spinarichthys dispersus scales. Using a comparison of both the process and the scale it is possible to verify on M 4895 (Fig. 13B), that the peg is $0.8 \mathrm{~mm}$ deep, and the scale is $2 \mathrm{~mm}$ deep and $3.5 \mathrm{~mm}$ long. The scales from the posterior region of the body have small peg and socket articulation (Fig. 13C, D). Examination of the scales with SEM disclosed numerous small microtubercles on the lateral ganoine surface of the scales. Although the microtubercles were partly raspared during transport of the scales in aquatic environments, they are observable on the ganoine surface of the scales, and they are partly linear in some parts. Arrangement and shape of the microtubercles could be a diagnostic feature for determination of isolated scales of Permo-Carboniferous actinopterygians, as already Meunier et al. (1986), Gayet \& Meunier (2001) have demonstrated for recent and fossil genera of Lepisosteiformes and Polypteriformes. The isolated operculum (MHK 81338) is tall, and anteriorly bent in the dorsal region. It is longest is in its dorsal region, and is narrow ventrally.

Remarks. - Spinarichthys dispersus was initially described from the Stephanian B, C of the Kladno-Rakovník Basin of the Bohemian Massif (Fritsch 1894; Stamberg 1986, 2013; Štamberg \& Zajíc 2008) on the basis of body fragments and isolated scales. Spinarichthys dispersus is an important taxon in the family Aeduellidae, and the finds of scales in the Krkonoše Piedmont Basin document a wider distribution of this species in the Bohemian Massif and expansion of the family Aeduellidae in the Late Carboniferous. The Aeduellidae is a very interesting family within the actinopterygians. It is characterised by several specific features (Poplin \& Dutheil 2005), which allow reliable determination and monitoring of their distribution. They were first known by several species from the Permian sediments of the French Massif Central (Heyler 1969), but subsequent research confirmed their distribution to be over a much longer time segment and a much larger geographic area. The oldest member of the family Aeduellidae is Bourbonnella jocelynae Mickle, 2011 from the Manning Canyon Shale Formation from Central Utah, and it belongs to the Upper Mississipian-Lower Pennsylvanian (Mickle 2011), which corresponds to the European Namurian. If the placement of Bourbonnella jocelynae among the Aeduellidae and the age of sediments are correct, this species is the oldest occurrence of the family Aeduellidae, being $20 \mathrm{Mi}$ years older than other species of Aeduellidae from the USA and Europe. Other species of the family Aeduellidae come from the Upper Carboniferous and Lower Permian of the USA (Kinney Brick Quarry), the Puertollano Basin in Spain, Montceau-les-Mines, Decazeville, Autun Basin, Aumance Basin and Bourbon l'Archambault in France, Weiach in northern Switzerland, Thuringia and the Saar-Nahe Basin in Germany, the Kladno-Rakovník Basin, Krkonoše Piedmont Basin and Boskovice Graben in Bohemia, the Czech Republic (Poplin \& Dutheil 2005; Schindler 2007; Štamberg 2007, 2010, 2013). Their greatest expansion is recorded in the Lower Permian continental basins of Europe. Mass occurrences of some species such as Aeduella blainvillei in the locality Muse in the Autun Basin (Heyler 1969) or Neslovicella rzehaki in the Boskovice Graben (Štamberg 2007) were also recorded.

The environments of Aeduellidae are mostly interpreted as freshwater deposits (Poplin 1994, Roscher \& Schneider 2006, Carrol et al. 1991, etc.), but their reinterpretation as marine or influenced by marine environments was published more recently (Soler-Gijón \& Moratalla 

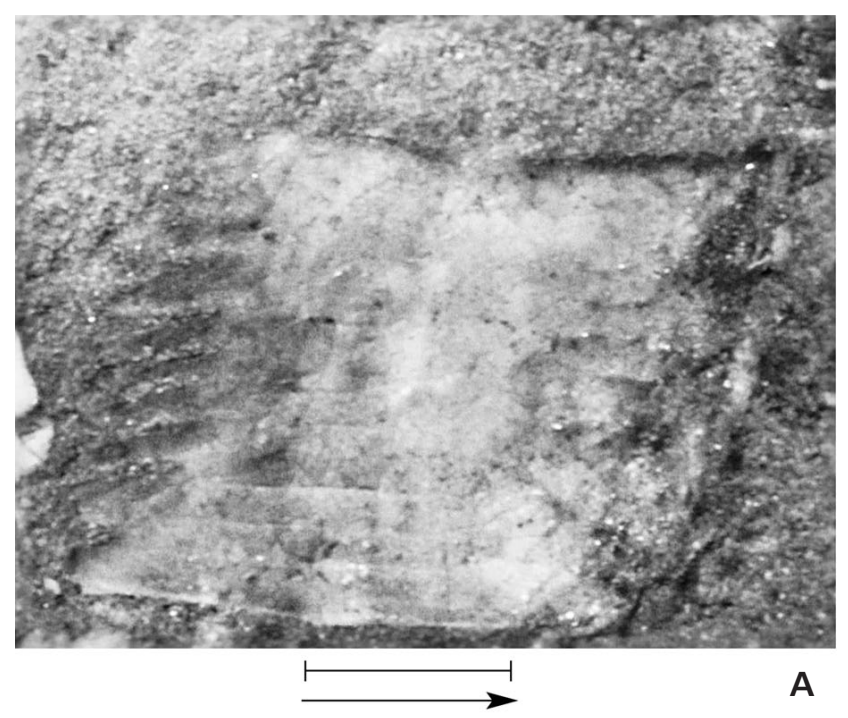

A

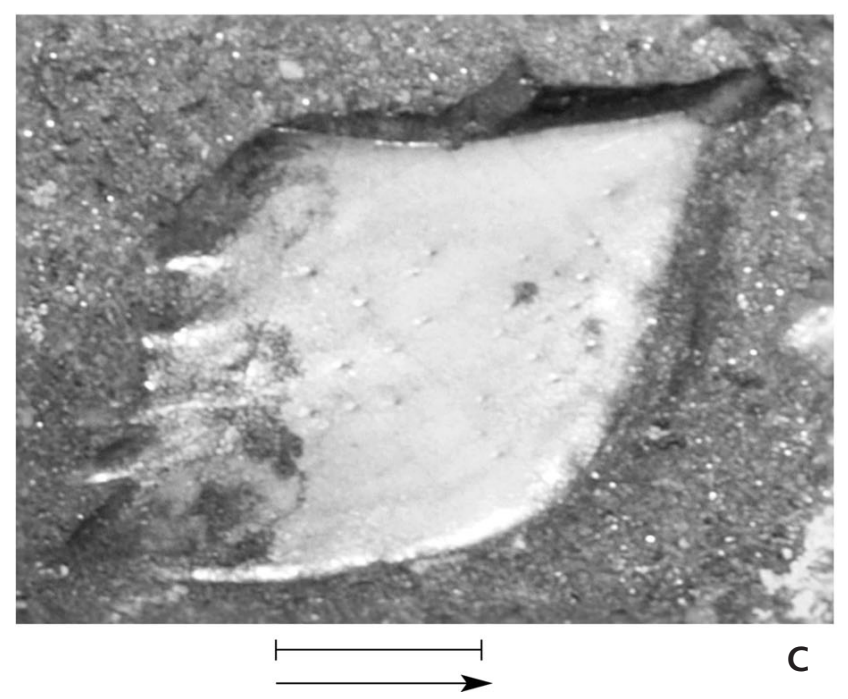

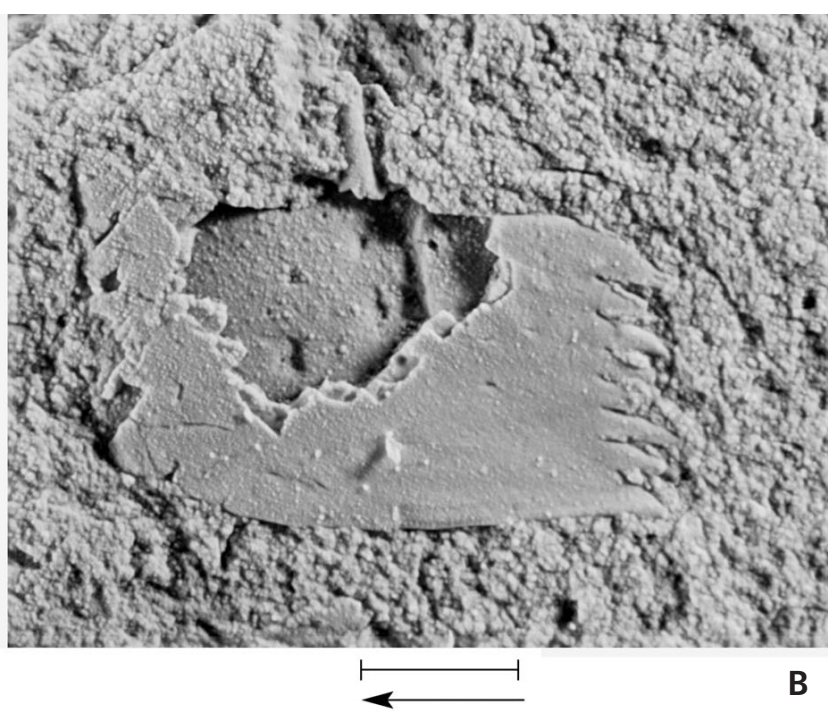

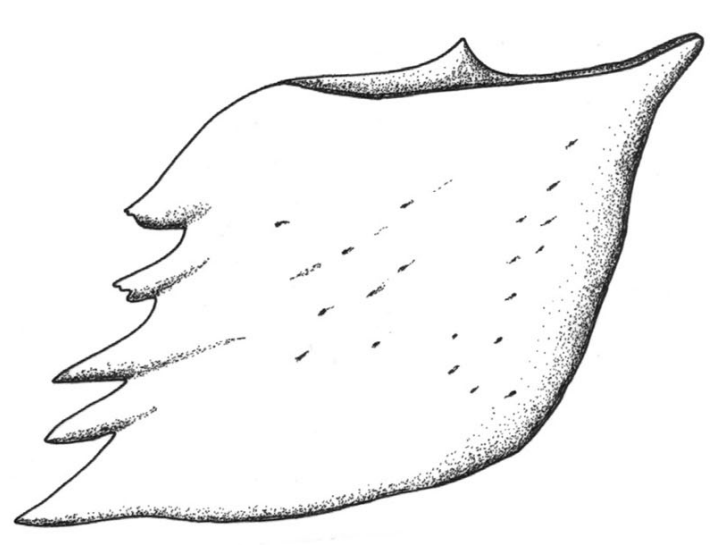

D

Figure 13. Spinarichthys dispersus (Fritsch, 1894). Isolated scales. Scale bars $1 \mathrm{~mm}$. Arrows indicate directio cranialis. $\bullet$ A - the scale from the anterior region of the lateral side of the body. GBW 2006/57/20, locality Kyje. $\bullet$ B - the scale with well preserve slender and long process of the peg and socket articulation. M 4895, locality Ploužnice. $\bullet$ C, D - photo and drawing of the flank scale of the posterior region of the body with small peg and socket articulation and very narrow overlapped area anteriorly. GBW 200/54/39, locality Žd'ár u Kumburku.

2001, Schultze \& Soler-Gijón 2004, Schultze 2009). I assume Bourbonnella sp. (Gottfried 1987) from Kinney Brick Quarry, New Mexico, is from beds that had an estuarine environment where is the mixture of organisms that are only freshwater in origin with organisms that are only marine in origin (Williams \& Lucas 2013). Williams \& Lucas (2013) speculated about the possibility of Bourbonnela sp. living in freshwater, and being washed into the estuary post-mortem, or if this fish was a freshwater stragler, which was in the Kinney estuary by mistake. In the case of the Bourbonnella sp. specimen, which was described by Gottfried (1987) the significant disarticulation of the body could indicate the effects of decomposition. Bourbonnella sp. specimens from the estuarine environment of Kinney Brick Quarry however are more numerous and better preserved without any decomposition as I observed during the course of a visit there in 2013 and also in the collection of the New Mexico Museum of Natural History and Science. For this reason I assume the fish was living in estuarine environment and by chance wandered into the marine environment. Bourbonnella was probably less sensitive to salinity and can, in agreement with Poplin's (2001) opinion be regarded as a euryhaline form, and it migrates through marine into freshwater.

I did not place the species Schafeevus sulcatus Yankevich \& Minich, 1998 from the Early Permian of East European Russia among the Aeduellidae. This species was described by Yankevich \& Minich (1998) on the basis of isolated scales only, and I consider the classification of this species to the Aeduellidae as insufficiently documented. 
Family Trissolepidae Fritsch, 1893

\section{Genus Sphaerolepis Frič, 1877}

Type species. - Sphaerolepis kounoviensis (Frič, 1876).

\section{Sphaerolepis kounoviensis (Frič, 1876)}

Figures 14-18

Material. - More than a hundred isolated scales usually preserved as casts, the best are on GBW 2004/54/42, LS85-Št1, MHK 64206, MHK 81330, MHK 81331, MHK 81336,MHK 81337, MHK 81339, MHK 81342, MHK 81346, MHK 81350, MHK 81353, parasphenoid (M 4891), upper jaw (MHK 82662, GBW 2006/54/3, GBW 2006/57/14), tooth plate (GBW 2006/54/30), and cleithrum (GBW 2006/57/21, M 4893, M 4894).

Occurrence. - Samples originate from the Semily Formation (Stephanian C), specifically from the Ploužnice Lake Deposits - localities: Ploužnice, Kyje, Žd'ár u Kumburku, Krsmol; Štěpanice-Čikvásky Lake Deposits - localities: Koštálov - "Dump of the Naděje adit", Koštálov "Bosna", Koštálov - borehole KV-1, Kouty - "Dumps of the Adolf nad Glück adits", Nedvězí "Dump of the Rohan adit", "Dump of the Otto adit" and Sutice near Slaná u Semil.

Description. - Isolated thin scales of a circular shape, slightly antero-posteriorly elongated, with an average diameter of 2 to $3.5 \mathrm{~mm}$. The focus is in the center of the scale. Anterior area of the scale is overlapped by posterior, ventral parts and dorsal parts of the neighbouring scales. Up to $75-80 \%$ of the outer surface is overlapped by the neigbouring scales, and only $20-25 \%$ of the outer surface remains exposed field. The overlapped region of the scale has regularly arranged incremental concentric ridges - circuli. The exposed field of the scale exhibits conspicuous sculptures in form of sharply pointed, posteriorly orientated protuberances (GBW 2006/54/42, LS85-Št1). Protuberances distribution on the uncovered region of the scales correspond the regularly concentrically arranged incremental circle (Figs 14A, 15A) on well preserved scales. Morphology of the scales of Sphaerolepis kounoviensis demonstrates spined scales of ctenoid type (Roberts 1993), and these scales are exclusive among the scales of Palaeozoic actinopterygians.

Isolated basal fulcra are anteriorly deeply cleft, slender, and elongated posteriorly to a point (Fig. 15B). Their determination is based on the comparison with the basal fulcra on the complete specimens from the Kounov Member of the Kladno Rakovník Basin.

The cleithrum is another relatively frequently found bone of Sphaerolepis kounoviensis. It has (Fig. 16A) a ver- tical branch, which is narrow and elongated dorso-ventrally, the horizontal branch projects conspicuously to the process anteriorly (M 4893, M 4894, LS 85, GMB $2006 / 57 / 21$ ). Only the long anterior process is diagnostic for the cleithrum of Sphaerolepis kounoviensis.

The maxilla is preserved on three specimens. It consists of a square shaped maxillary plate and a long narrow anterior region with the remains of teeth (Figs 17A, 18). No sculpture is observable on the bone due to the preservation of the imprint of the bone.

The vomer on GBW 2006/54/30 shows the teeth in cross-section on the whole ventral surface (Fig. 17B). The cross-sections of the teeth are visible because of abrasion of the distal part of the teeth. The diameter of the teeth increases from one side of the bone to the opposite side of the ventral surface of the vomer. It can be deduced from analogous study of more complete specimens from the Central and West Bohemian Late Paleozoic basins (Štamberg 1991), that the smaller teeth occupied the lateral region of the vomer increasing towards medial direction.

The parasphenoid is a characteristic bone of the Sphaerolepis kounoviensis. In addition to the single pair of processus ascendens posterior, anteriorly prolongated processus cultriformis are present, there is also a significantly prolongated posterior region of the corpus parasphenoidis, which is a relatively rare feature among the Permo-Carboniferous actinopterygians. The corpus parasphenoidis of most Permo-Carboniferous actinopterygians terminates posteriorly close behind the posterior processus ascendens. The sample M 4891 from the Ploužnice Lake Deposits shows the parasphenoid in dorsal view (Fig. 16B) with a partly broken off anterior part of the processus cultriformis. The pair of ascending processus ascendens projects at an angle of $45^{\circ}-50^{\circ}$ to the axis of the corpus parasphenoidis. The large opening of the bucco-hypophysial foramen is situated in the centre of the parasphenoid. The posterior region of the corpus parasphenoidis is significantly extended posteriorly to a length of $9.5 \mathrm{~mm}$ (measured from the bucco-hypophysial foramen to the posterior end of the corpus parasphenoidis). The posterior prolongated region of the corpus parasphenoidis is lobed, similar to in Broughia (Stensiö 1932), and without any conspicuous notch (aortic notch), which is described for example by Grande \& Bemis (1998) on Amia calva.

Remarks. - Sphaerolepis kounoviensis achieved considerable expansion in the Stephanian deposits of the Bohemian Massif. The most numerous finds of Sphaerolepis kounoviensis, in addition to those from the Krkonoše Piedmont Basin, come from the Kounov Member (Stephanian B) of the Kladno Rakovník Basin and from other localities of Stephanian B and Stephanian C of the Central and Western Bohemian basins (Štamberg 1991; Štamberg \& Zajíc 2000, 2008). The occurrence of Sphaerolepis kouno- 

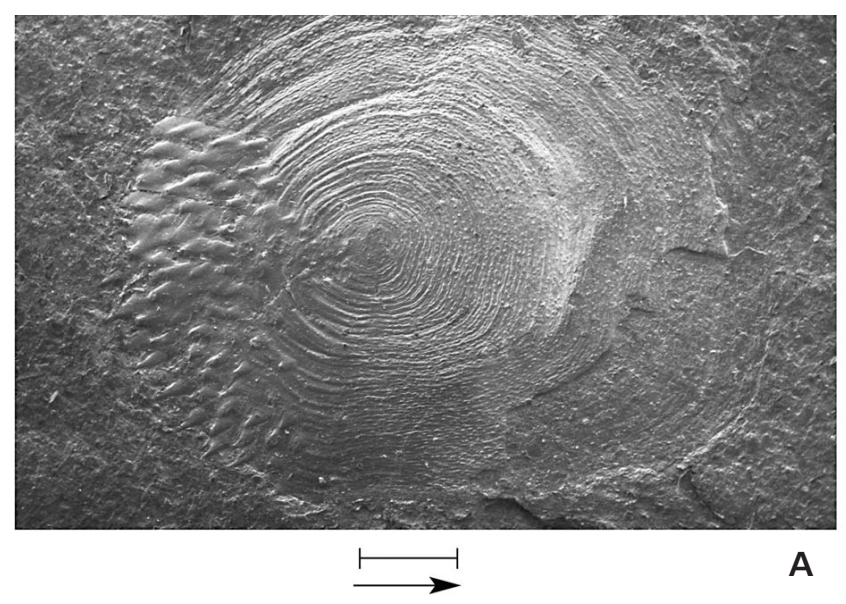

A

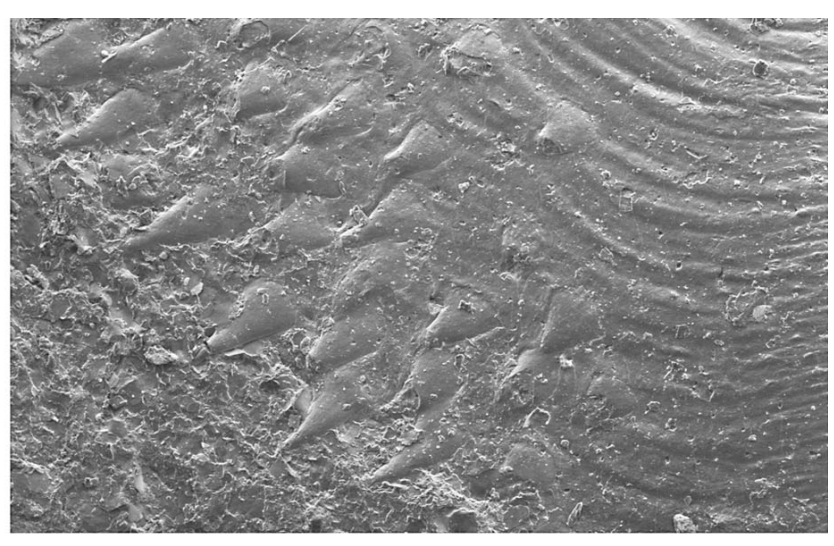

B

Figure 14. Sphaerolepis kounoviensis (Frič, 1876). Isolated scale LS 85-Št1, locality Sutice. Scale bars $500 \mu \mathrm{m}$. Arrow indicates directio cranialis. - A - whole scale. $\bullet \mathrm{B}$ - detail of sharply pointed posteriorly oriented protuberances.

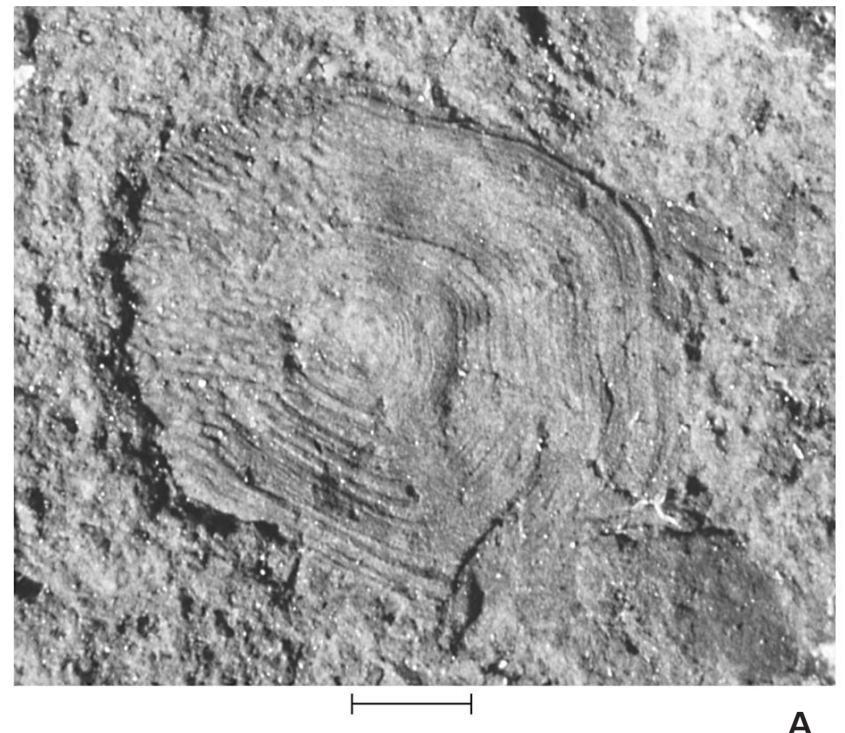

viensis was also confirmed from Stephanian C of the Intrasudetic Basin (Štamberg 2003). It is obvious that this species migrated among the basins of the Bohemian Massif in the Late Carboniferous and constituted a permanent resident. The occurrence of Sphaerolepis kounoviensis is restricted to the deposits of the Late Carboniferous only, it does not occur in the Permian sediments of the Bohemian Massif.

The genus Sphaerolepis is reported from two other regions in addition to the Bohemian Massif. Small fragments of bones and teeth were described from the Permo-Carboniferous sediments of Illinois and Texas and classed by Cope (1877) as Peplorhina arctata Cope, 1877 and later (Case 1900) as the genus Sphaerolepis. Later Ørvig (1978) classified them as Sphaerolepis cf. arctata (Cope, 1877). The figures of poorly preserved specimens include fragments of the vomer or dermal bones of the medial region of

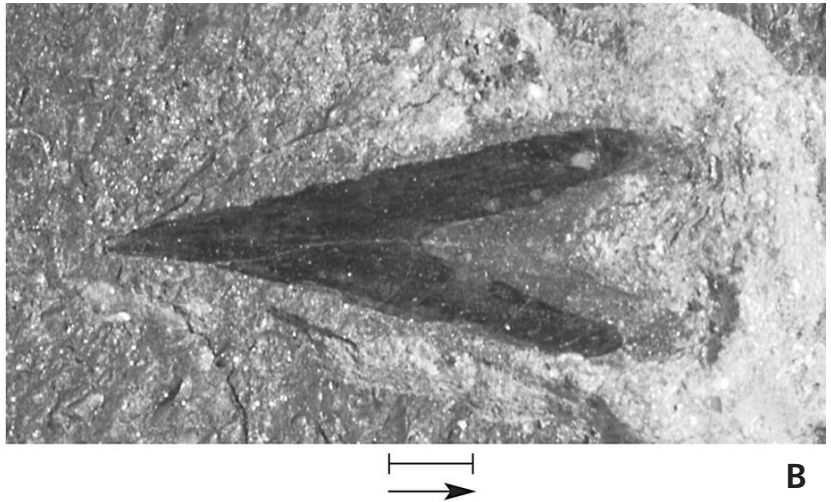

Figure 15. Sphaerolepis kounoviensis (Frič, 1876). - A - flank scale. GBW 2006/54/42, locality Ždár u Kumburku. Scale bar 1 mm. • B - ridge scale from the dorsal side of the tail. MHK 81342, locality Nedvězí "Dump of the Otto adit". Scale bar $1 \mathrm{~mm}$, arrow indicates directio cranialis.

the palatoquadrate, and they should not be classified as Sphaerolepis.

Bürgin (1990) reported the genus Sphaerolepis from the continental sediments of the North Swiss Permocarboniferous Basin. A fragment of trunk described as cf. Sphaerolepis plus fragments of Aeduella sp. and scales and fragment of cf. Paramblypterus fin were described by Bürgin (1990) from a core drill at Weiach. The studied part of the core drill is Early Permian in age, and the occurrence of typical Permian genera Aeduella and Paramblypterus confirm this. Radiometric dating of zircons from the ash layers confirmed an age of $298 \mathrm{Ma}$ (McCann et al. 2006) for the most upper layers of this borehole. The fragment of the anterior region of the trunk classified as cf. Sphaerolepis exhibits cycloidal form scales with concentrically arranged incremental concentric ridges. The sharply pointed posteriorly orientated protruberances, which are 


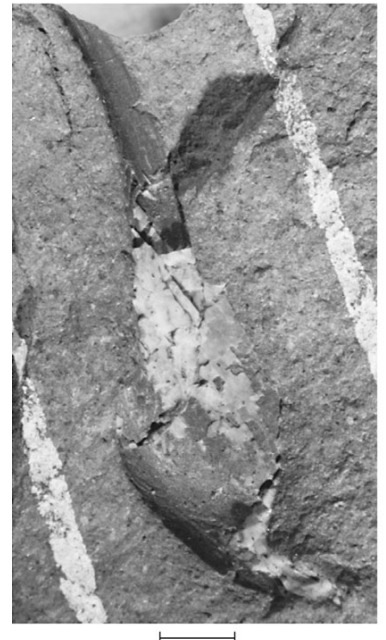

A

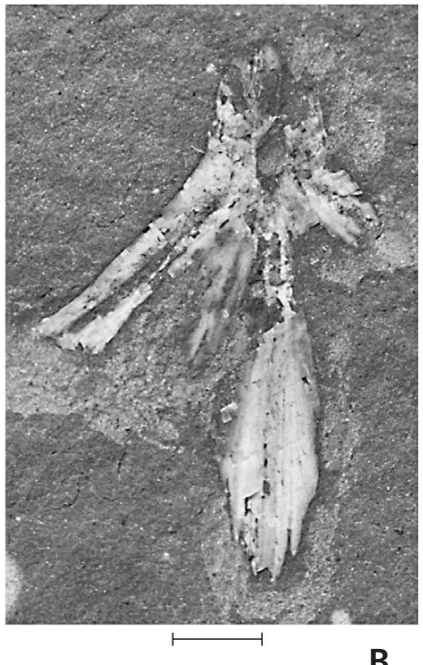

B
Figure 16. Sphaerolepis kounoviensis (Frič, 1876). • A - right cleithrum in lateral view. GBW 2006/57/21, locality Kyje. Scale bar 2 mm. • B fragment of the parasphenoid in dorsal view. M 4891, locality Ploužnice. Scale bar $2 \mathrm{~mm}$.

typical just in anteriorly located scales of Sphaerolepis kounoviensis, were not observed, and no distinction between uncovered and overlapped surfaces of the scales was evident. Due to the above mention factors I assume that the classification of the body fragment as Sphaerolepis is very uncertain.

At present it appears that the genus Sphaerolepis with the species Sphaerolepis kounoviensis was restricted to the Stephanian B and C of the Bohemian Massif basins.

\section{Taphonomic comments}

Disarticulated fragments of actinopterygians from the Carboniferous sediments of the Krkonoše Piedmont Basin are represented by isolated bones and mainly by isolated scales and teeth. It is evident that the remains of the fishes following death and decomposition were transported variable distances. Some teeth and scales exhibit considerable abrasion of their outer surface or sculpture. Many teeth and scales on the other hand retain the delicate sculptures on their outer surface. It is obvious the fragments were probably transported over varying distances, and moreover, if the skeletal fragments were transported together over a soft muddy substrate their abrasion was reduced. The scales and teeth from the grey-black mudstones of the Štěpanice-Čikvásky Lake Deposits (localities: Nedvězí "Dump of the Rohan adit", "Dump of the Otto adit", Sutice) demonstrate much less abrasion than those from the "bonebed" horizon (Frič 1912a, b) from the Ploužnice Lake Deposits (localities: Ploužnice, Ždár u Kumburku "Smita"). The latter represents a layer of about only $5 \mathrm{~mm}$ thickness of pinkish mudstone with an accumulation of actinopterygian fragments, as well as other vertebrates, and it reflects their accumulation from over a large area of the lake.

Fragments of Progyrolepis speciosus, "Elonichthys" sp. and Spinarichthys dispersus were identified from the Syřenov Formation (Stephanian B). No scales or other fragments of Sphaerolepis kounoviensis have been found in Stephanian B of the Krkonoše Piedmont Basin. Sphaerolepis kounoviensis is on the contrary most abundant in the sediments of the Semily Formation (Stephanian C), and it occurs there together with Progyrolepis speciosus, "Elonichthys" sp. and Spinarichthys dispersus. These actinopterygians lived in the same environment. These findings are documented not only in the same localities but also with findings of different species together in the same sample. For example the small sample MHK 81330 contains the fragments of "Elonichthys" sp., Sphaerolepis kounoviensis and Spinarichthys dispersus. Sphaerolepis kounoviensis is most abundant in the locality Nedvězí "Dump of the Otto adit" specifically in the layer with an accumulation of ostracods. I can assume the ostracods formed the main diet of Sphaerolepis kounoviensis.

Palaeogeography of Ploužnice Lake and distinctions between the Štěpanice-Čikvásky area and Ploužnice area of the Ploužnice Lake are explained in the papers of Prouza \& Tásler (2001) and Zajíc (2007). It should be added that the composition of the actinopterygian fauna is the same in the both areas. The difference is in the occurrence of insects. Numerous wings of blattodean insects are known from the Ploužnice area (Kyje, Ploužnice, Ždár u Kumburku), while they are absent in the Štěpanice-Čikvásky area (Štamberg \& Zajíc 2008). The occurrence of insect wings bears evidence to the proximity of the lakeshore. In addition, the anterior part of a myriapod body (GBW 2006/54/9) from the locality Ploužnice was discovered among the remains of actinopterygians in the collection of the Geological Survey in Vienna.

The above mentioned actinopterygian taxa are well known from the Stephanian B and Stephanian C of the Central and West Bohemian Upper Paleozoic basins. The occurence of Progyrolepis speciosus, "Elonichthys" sp., Spinarichthys dispersus and Sphaerolepis kounoviensis in the Stephanian sediments of the Krkonoše Piedmonmt Basin provides evidence for the interconnection of the Krkonoše Piedmont Basin and Central and West Bohemian Late Paleozoic basins during the course of Stephanian B and $\mathrm{C}$.

\section{Conclusions}

Progyrolepis speciosus, "Elonichthys" sp., Spinarichthys dispersus and Sphaerolepis kounoviensis from the Carboniferous sediments of the Krkonoše Piedmont Basin can be 


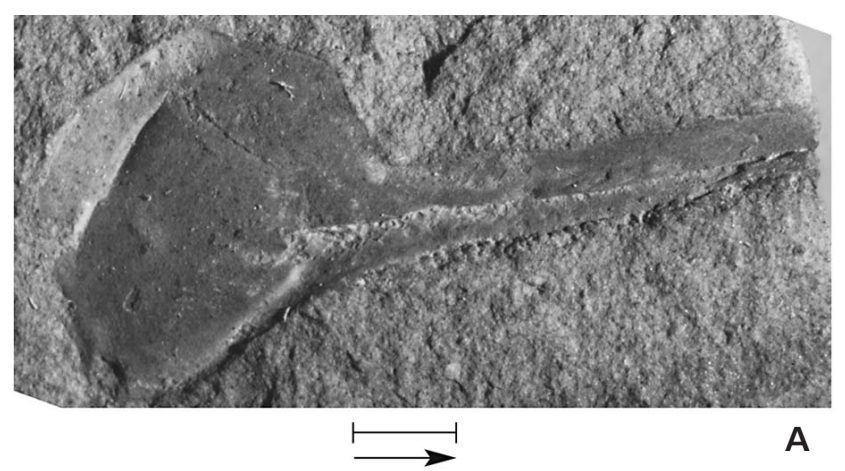

Figure 17. Sphaerolepis kounoviensis (Frič, 1876). • A - right maxilla in lateral view. GBW 2006/54/3, locality Kyje. Scale bar $2 \mathrm{~mm}$, arrow indicates directio cranialis. • B - vomer in ventral view. GBW 2006/54/30, locality Žd’ár u Kumburku. Scale bar $2 \mathrm{~mm}$, arrow indicates directio cranialis.

distinguished on the basis of isolated scales, bones and teeth. A comparative study of the actinopterygian fragments confirms the same actinopterygian fauna in the Central and West Bohemian Upper Palaeozoic basins, and provides evidence for an interconnection between these areas of accumulation during the Stephanian. The occurrence of the genus Progyrolepis documents the interconnection between the basins of the Bohemian Massif and the French Massif Central through river system and lakes. Isolated scales, as yet incompletely determined, of the genus Elonichthys were compared with "Elonichthys" krejcii from the Carboniferous of the Central and West Palaeozoic basins, and they demonstrate features consistent with those of the type species Elonichthys germari from the Upper Carboniferous of the Halle Basin. Spinarichthys dispersus complements a population of the family Aeduellidae in the basins of the Bohemian Massif. Spinarichthys dispersus inhabited the freshwater environment of the Stephanian B and $\mathrm{C}$ of the Bohemian Massif and belongs to one of the first aeduellids finds in the Permo-Carboniferous basins of Europe. However the origin of the monophyletic group of Aeduellidae should probably be searched for on the border of the Mississippian and Lower Pennsylvanian in North America. Sphaerolepis kounoviensis with its typical cycloidal shaped scales and conspicuous protuberances on the lateral side was an inhabitant of the Krkonoše Piedmont Basin, Intrasudetic Basin and the Central and West Bohemian Late Palaeozoic basins in the Stephanian B and C. A trunk fragment with scales of cycloidal form but without protuberances from the continental Permian deposits of the North Swiss Permocarboniferous Basin should not be assigned to Sphaerolepis for the present. Detailed documentation of isolated scales and skeletal fragments will make determination of future findings easier. Microscopic exa-
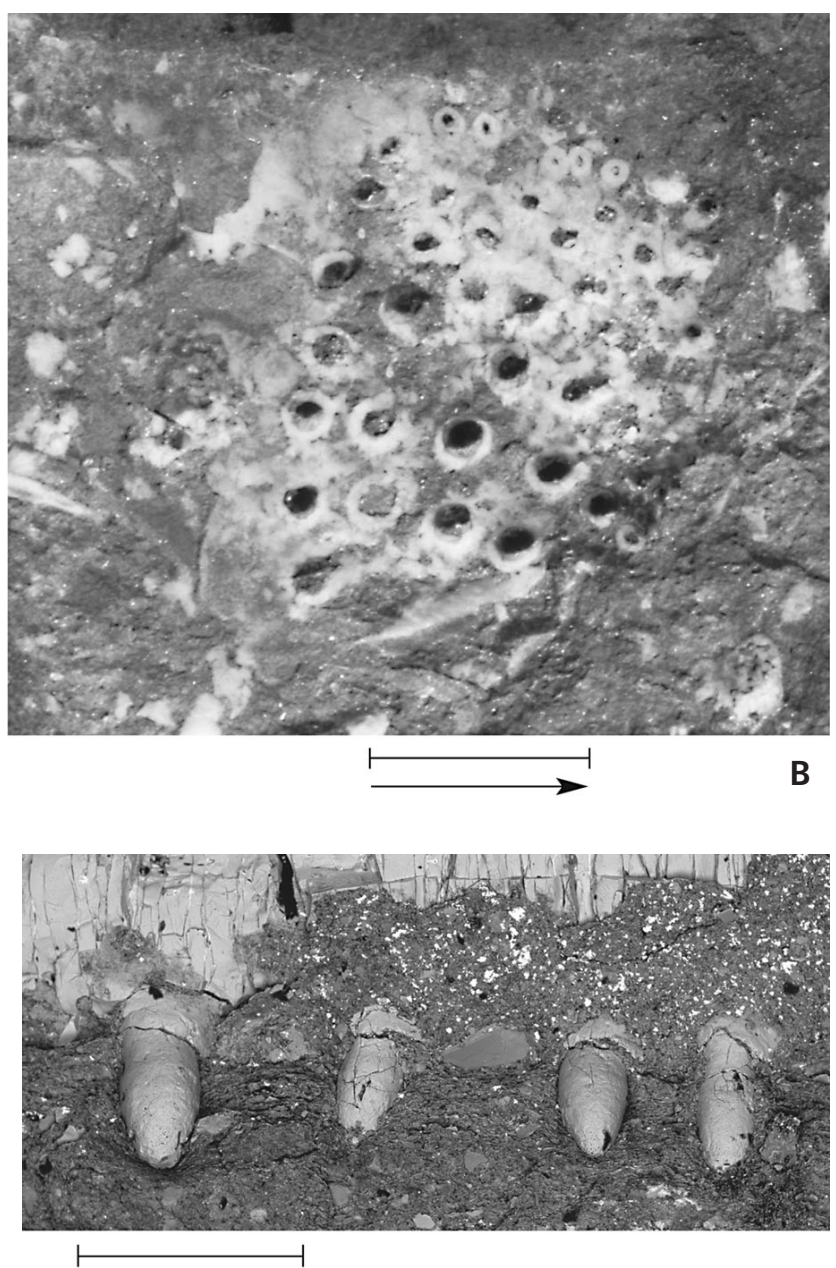

Figure 18. Sphaerolepis kounoviensis (Frič, 1876). Part of the maxilla with teeth. MHK 82662, locality Nedvězí "Dump of the Otto adit". Scale bar $500 \mu \mathrm{m}$.

mination of the teeth of "Elonichthys" sp., Progyrolepis speciosus and Progyrolepis heyleri document the absence of longitudinal striae on the periphery of "Elonichthys" teeth, but on the contrary their presence in both species of Progyrolepis. The elliptical protuberances, proximodistally elongated and densely packed, form the microsculpture on the teeth of "Elonichthys" sp., Progyrolepis speciosus and $P$. heyleri. Elliptical protuberances arranged in several convolutions are not a feature of only Progyrolepis speciosus, but the same arrangement can be seen on the teeth of Progyrolepis heyleri. The study of scale microsculpture revealed a series of features. While the scales of Spinarichthys dispersus on their lateral side have numerous small microtubercles, a typical feature for ganoine, of a circular shape, the microtubercles on the scales of "Elonichthys" sp. are slightly antero-posteriorly elongated. The SEM study of scale and tooth microsculpture of "Elonichthys" sp., Progyrolepis heyleri and Spinarichthys dispersus, disclosed microtubercles whose shape and 
arrangement may be an important feature, and aid determination of isolated fragments of Late Palaeozoic actinopterygians.

\section{Acknowledgements}

This study is a part of the research project IGCP 575, supported by the Czech National Committee for IGCP and the companies Severočeské doly, a.s., Eurovia CS, a.s., and Vápenka Vitoul, s.r.o. I am obligated to Irene Zorn (Geologische Bundesanstalt in Vienna), Norbert Hauschke (Martin-Luther University, Halle-Wittenberg), Petr Budil (Czech Geological Survey, Prague) and Boris Ekrt (National Museum, Prague) for access to material in their care, and to Lenka Váchová and Boris Ekrt (National Museum, Prague) for photographs on Electron Microscope, and to Mrs Gill Horálek for linguistic correction of the English. I thank reviewer H.-P. Schultze (University of Kansas) and an anonymous reviewer for providing helpful comments which greatly improved the quality of the manuscript.

\section{References}

BÜRgIN, T. 1990. Palaeonisciden (Osteichthyes: Actinopterygii) aus dem Unteren Rotliegenden (Autunien) der Nordschweiz. Eclogae geologicae Helvetiae 83(3), 813-827.

CASE, E.C. 1900. The vertebrates from the Permian bone-bed of Vermilion county, Illinois. Journal of Geology 8, 698-729. DOI 10.1086/620866

Carrol, R.L., Bybee, P. \& Tidwell, W.D. 1991. The oldest microsaur (Amphibia). Journal of Paleontology 65, 314-322.

Cope, E.D. 1877. On the Vertebrata of the bone bed in Eastern Illinois. Proceedings of the American Philosophical Society 17, 52-63.

FRIČ, A. 1912a. Studie v oboru českého útvaru permského. Archiv pro přirodovědecký výzkum Čech 15(2), 1-48.

FRIČ, A. 1912b. Studien im Gebiete der Permformation Böhmens. Archiv für die naturwissenschaftliche Landesdurchforschung Böhmens 15(2), 1-52.

FRITSCH, A. 1894. Fauna der Gaskohle und der Kalksteine der Permformation Böhmens. Band 3, Heft 2, 81-104. F. Řivnáč, Praha.

Fritsch, A. 1895. Fauna der Gaskohle und der Kalksteine der Permformation Böhmens. Band 3, Heft 4, 105-132. F. Řivnáč, Praha.

GardineR, B.G. 1963. Certain palaeoniscoid fishes and the evolution of the snout in actinopterygians. Bulletin of the British Museum (Natural History) 8(6), 257-325.

Gayet, M. \& Meunier, F.J. 2001. A propos de genre Paralepidosteus (Ginglymodi, Lepisosteidae) du Crétacé Gondwanien. Cybium 25(2), 153-159.

Giebel, C.G. 1849. Fischüberreste, 69-79. In Germar, E.F. Versteinerungen des Steinkohlengebirges von Wettin und Löbejün im Saalkreise 6. Schwetschke und Sohn, Halle.
GotTfried, M.D. 1987. A Pennsylvanian aeduelliform (Osteichthyes, Actinopterygii) from North America with comments on aeduelliform interrelationships. Paläontologische Zeitschrift 61(1/2), 141-148. DOI 10.1007/BF02985947

Grande, L. \& Bemis, W.E. 1998. A comprehensive phylogenetic study of amiid fishes (Amiidae) based on comparative skeletal anatomy. An empirical search for interconnected patterns of natural history. Journal of Vertebrate Paleontology 18(1), supplement Memoirs (1-4), 1-690.

Heyler, D. 1969. Vertébrés de l'Autunien de France. 255 pp. Cahiers de Paléontologie, Éditions du Centre National de la Recherche Scientifique, Paris.

MartíneK, K., Blecha, M., DaněK, V., Francư, J., Hladíková, J., Johnová, R. \& UličnÝ, D. 2006. Record of palaeoenvironmental changes in a Lower Permian organic-rich lacustrine succession: Integrated sedimentological and geochemical study of the Rudník member, Krkonoše Piedmont Basin, Czech Republic. Palaeogeography, Palaeoclimatology, Palaeoecology 230, 85-128.

DOI 10.1016/j.palaeo.2005.07.009

McCann, T., Pascal, C., Timmerman, M.J., Krzywiec, P., López-Gómez, J., Wetzel, A., Krawczyk, C.M., Rieke, H. \& Lamarche, J. 2006. Post-Variscan (end Carboniferous - Early Permian) basin evolution in Western and Central Europe, 355-388. In Gee, D.G. \& Stephenson, R.A. (eds) European Lithosphere Dynamics. Geological Society of London, Memoirs 32. The Geological Society of London, London. DOI 10.1144/GSL.MEM.2006.032.01.22

Meunier, F.J., Gayet, M., Géraudie, J., Sire, J.-Y. \& ZylberBERG, L. 1986. Données Ultrastructurales sur la Ganoïne du Dermosquelette des Actinoptérygiens Primitifs. Mémoires $d u$ Muséum National d'Histoire Naturelle, Paris, série C 53, 77-83.

MickLe, K.E. 2011. The early actinopterygian fauna of the Manning Canyon Shale Formation (upper Mississippian, lower Pennsylvanian) of Utah, U.S.A. Journal of Vertebrate Paleontology 31(5), 962-980.

DOI 10.1080/02724634.2011.595622

ØRVIG, T. 1978. Microstructure and growth of the dermal skeleton in fossil actinopterygian fishes: Nephrotus and Colobodus, with remarks on the dentition in other forms. Zoologica Scripta 7, 297-326.

DOI 10.1111/j.1463-6409.1978.tb00613.x

Poplin, C. 1994. Montceau-les-Mines, bassin intramontagneux carbonifère et permien de France: reconstitution, comparaison avec d'autres bassins d'Euramérique, 289-328. In Poplin, C. \& HeYler, D. (eds) Quand le Massif Central était sous l'équateur: un écosystème carbonifère à Montceau-les-Mines. Mémoires de la Section des Sciences 12.

Poplin, C. 1999. Un paléoniscoide (Pisces, Actinopterygii) de Buxières-les-Mines, témoin des affinités fauniques entre Massif Central et Bohême au passage Carbonifère-Permien. Geodiversitas 21(2), 147-155.

Poplin, C. 2001. Le genre Bourbonnella (Actinopterygii, Aeduellidae): révision et description d'une nouvelle espèce du Stéphanien (Carbonifère supérieur) de Montceau-les-Mines 
(Massif Central, France). Annales de Paléontologie 87(4), 231-248. DOI 10.1016/S0753-3969(01)80012-4

Poplin, C. \& Dutheil, D.B. 2005. Les Aeduellidae (Pisces, Actinopterygii) carbonifères et permiens: systématique et étude phylogénétique préliminaire. Geodiversitas 27(1), 17-33.

Poschmann, M. \& Schindler, T. 2004. Sitters and Grügelborn, two important fossil-Lagerstaetten in the Rotliegend (?Late Carboniferous - Early Permian) of the Saar-Nahe Basin (SW-Germany), with the description of a new palaeoniscoid (Osteichthyes, Actinopterygii). Neues Jahrbuch für Geologie und Paläontologie, Abhandlungen 232(2/3), 283-314.

Prouza, V. \& TÁsler, R. 2001. Podkrkonošská pánev, 128-166. In PEŠEK, J. et al. (ed.) Geologie a ložiska svrchnopaleozoických limnických pánví České republiky. Český geologický ústav, Praha.

Richter, M. 1995. Actinopterygian scale microstructure as a tool in the biostratigraphy of the Palaeozoic. Boletin de la Academia Nacional de Ciencias, Cordoba 60 $\left(3^{a}-4^{a}\right), 545-553$.

RoBERTS, D.C. 1993. Comparative morphology of spined scales and their phylogenetic significance in the Teleostei. Bulletin of Marine Science 52(1), 60-113.

Roscher, M. \& Schneider, J.W. 2006. Permo-Carboniferous climate: Early Pennsylvanian to Late Permian climate development of central Europe in a regional and global context, 95-136. In Lucas, S.G., CAssinis, G. \& Schneider, J.W. (eds) Non-Marine Permian Biostratigraphy and Biochronology. Geological Society of London, Special Publications 265.

SchindLeR, T. 2007. Knochenfische (Osteichthyes). Die häufigsten Wirbeltiere permokarbonischer Seen, 240-256. In SCHIndLER, T. \& HeIDTKE, U.H.J. (eds) Kohlesümpfe, Seen und Halbwüsten. Pollichia, Sonderveröffentlichung 10.

SCHINDLER, T. 2009. Tierisches aus dem Oberkarbon: Wettin ist auch für Fische gut. Fossilien 6, 363-366.

Schneider, J.W., Rössler, R., Gaitzsch, B.G., Gebhardt, U., Kampe, A. \& Breitkreuz, C. 2005. Saale-Senke. Courir Forschungsinstitut Senckenberg 254, 419-440.

Schultze, H.-P. 2009. Interpretation of marine and freshwater paleoenvironments in Permo-Carboniferous deposits. Palaeogeography, Palaeoclimatology, Palaeoecology 281, 126-136. DOI 10.1016/j.palaeo.2009.07.017

Schultze, H.-P. 2015. Scales, Enamel, Cosmine, and Early Osteichthyans. Comptes Rendus Palevol, 1-21.

DOI 10.1016/j.crpu.2015.04.001

Schultze, H.-P. \& Soler-GiJón, R. 2004. A xenacanth clasper from the ?uppermost Carboniferous - Lower Permian of Buxières-les-Mines (Massif Central, France) and the palaeoecology of the European Permo-Carboniferousd basins. Neues Jahrbuch für Geologie und Paläontologie, Abhandlungen 232(2/3), 325-363.

SOLER-GiJón, R. 1997. Euselachian sharks from the Late Carboniferous of the Puertollano Basin, Spain: biostratigraphic and palaeoenvironmental implications. Modern Geology 21, $137-169$.

Soler-Gijón, R. \& Moratalla, J.J. 2001. Fish and tetrapod trace fossils from the Upper Carboniferous of Puertollano, Spain.
Palaeogeography, Palaeoclimatology, Palaeoecology 171, 1-28. DOI 10.1016/S0031-0182(01)00257-7

STENSIÖ, E. 1932. Triassic fishes from East Greenland collected by the Danish Expeditions in 1929-1931. Meddelelser om Grønland 83, 1-305.

ŠTAmBerg, S. 1985. Poissons permocarbonifères de Tchécoslovaquie. Bulletin Trimestriel de la Société d'Histoire Naturelle et des Amis du Muséum d'Autun 116(3), 99-113.

ŠTAmberG, S. 1986. Fish Spinarichthys dispersus (Actinopterygii) from the Carboniferous of Bohemia. Acta Universitatis Carolinae, Geologica, Špinar Vol. 2, 155-169.

ŠTAMBERG, S. 1989. Scales and their utilization for the determination of actinopterygian fishes (Actinopterygii) from Carboniferous basins of Central Bohemia. Časopis pro mineralogii a geologii 34(3), 255-269.

ŠtamberG, S. 1991. Actinopterygians of the Central Bohemian Carboniferous Basins. Acta Musei nationalis Pragae, Series B - historia naturalis 47(1-4), 25-104.

ŠTAMBERG, S. 2001. Fin spine of a ctenacanthoid shark (Elasmobranchii, Ctenacanthoidea) from the Upper Stephanian of the Krkonoše Piedmont Basin (Bohemia). Bulletin of the Czech Geological Survey 76(2), 141-148.

S̆TAmBERG, S. 2003. Paprskoploutvá ryba Sphaerolepis (Trissolepididae, Actinopterygii) ve vnitrosudetské pánvi. Zprávy o geologických výzkumech v roce 2002, 155-156.

Štamberg, S. 2007. Permo-Carboniferous Actinopterygians of the Boskovice Graben. Part 1. Neslovicella, Bourbonnella, Letovichthys, Elonichthys. 155 pp. Museum of Eastern Bohemia at Hradec Králové.

ŠTAmBERG, S. 2010. A new aeduellid actinopterygian from the Lower Permian of the Krkonoše Piedmont Basin (Bohemian Massif) and its relationship to other Aeduellidae. Bulletin of Geosciences 85(2), 183-198. DOI 10.3140/bull.geosci.1190

ŠTAmBerg, S. 2013. Knowledge of the Carboniferous and Permian actinopterygian fishes of the Bohemian Massif - 100 years after Antonín Frič. Acta Musei nationalis Pragae, Series B historia naturalis 69(3-4), 159-181.

ŠTAmBERG, S. \& Zajíc, J. 2000. New data on the osteology of actinopterygian fish Sphaerolepis kounoviensis. Věstník Českého geologického ústavu 75(4), 455-458.

Štamberg, S. \& Zajíc, J. 2008. Carboniferous and Permian faunas and their occurrence in the limnic basins of the Czech Republic. 224 pp. Museum of Eastern Bohemia at Hradec Králové.

Tásler, R., Havlena, V. \& Prouza, V. 1981. Nové litostratigrafické členění centrální a západní části podkrkonošské pánve. Věstník Ústředního ústavu geologického 56(3), 129-143.

Williams, S.C. \& Lucas, S.G. 2013. Taphonomy and paleoecology of Pennsylvanian fishes from the Kinney Brick Quarry, New Mexico, USA, 371-383. In LuCAS, S.G. et al. (eds) The Carboniferous-Permian Transition, New Mexico of Natural History and Science, Bulletin 59.

YANKEVICH, D.I. \& Minich, M.G. 1998. Ichthyofauna, 256-266. In Grunt, T.A., Esaulova, N.K. \& Kanev, G.P. (eds) Biota of East European Russia at the early/Late Permian boundary 
(International symposium "Upper Permian stratotypes of the Volga region”). GEOS, Moscow. [in Russian]

ZAJíc, J. 2000. Vertebrate zonation of the non-marine Upper Carboniferous - Lower Permian basins of the Czech Republic. Courier Forschungsinstitut Senckenberg 223, 563-575.

Zajíc, J. 2004. Vertebrate biozonation of the Permo-Carboniferous lakes of the Czech Republic - new data. Acta Musei reginaehradecensis, Series A 30, 16-17.
Zajíc, J. 2007. Carboniferous fauna of the Krkonoše Piedmont Basin. Acta Musei reginaehradecensis, Series A $32,11-16$.

ZAJíc, J. \& VAŠÍčEK, Z. 2010. Upper Carboniferous, Pennsylvanian, 181-183. In СнÁв et al. Outline of the Geology of the Bohemian Massif: the Basement Rocks and their Carboniferous and Permian Cover. Czech Geological Survey, Prague. 